Portland State University

PDXScholar

Spring 6-9-2015

\title{
Nationalism in United States Foreign Policy in the Post 9/11 Era
}

Chris W. Baum

Portland State University

Follow this and additional works at: https://pdxscholar.library.pdx.edu/open_access_etds

Part of the American Politics Commons, International Relations Commons, and the Peace and Conflict Studies Commons Let us know how access to this document benefits you.

\section{Recommended Citation}

Baum, Chris W., "Nationalism in United States Foreign Policy in the Post 9/11 Era" (2015). Dissertations and Theses. Paper 2531.

https://doi.org/10.15760/etd.2528

This Thesis is brought to you for free and open access. It has been accepted for inclusion in Dissertations and Theses by an authorized administrator of PDXScholar. Please contact us if we can make this document more accessible: pdxscholar@pdx.edu. 
Nationalism in Unites States Foreign Policy in the Post-9/11 Era

\title{
by
}

Christopher W. Baum

A thesis submitted in partial fulfillment of the requirements for the degree of

\author{
Master of Science \\ in \\ Conflict Resolution
}

Thesis Committee:

Harry Anastasiou, Chair

Rachel Cunliffe

Robert Gould

Portland State University

2015 


\begin{abstract}
One year after the terror attacks of September 11, 2001, the administration of President George W. Bush introduced a revolutionary foreign policy strategy — the Bush Doctrine. Proponents of this strategy advocated the use of American 'hard power' as a tool to promote freedom and democracy, beginning with the invasions of Afghanistan and Iraq. Opponents of the doctrine saw it as dangerously nationalistic, with the potential to entangle the United States in a myriad of protracted international conflicts. This thesis will identify aspects of nationalism within post-9/11 American foreign policy and illuminate the incompatibility of nationalism and the fundamental tenets of conflict resolution. This study theorizes that nationalism played a significant role in the development of the Bush Doctrine. Although its advocates promote specific policies historically associated with nationalism, as a rule they have not acknowledged its influence. Conversely, opponents of the doctrine acknowledge this influence and warn of its destructive characteristics. The study presented herein identifies nationalism as a powerful force in American culture and politics — one that has a profound influence on American foreign policy and on the longevity of our foreign wars.
\end{abstract}




\section{Table of Contents}

Abstract $\quad$ i

List of Tables $\quad$ iii

Chapter I: Introduction 1

Chapter II: Methodology

Chapter III: Literature Review 12

Chapter IV: Analysis and Discussion $\quad 34$

$\begin{array}{ll}\text { References } & 72\end{array}$ 


\section{List of Tables}

Table 1: Dominant Themes of Proponents and Opponents of the Bush Doctrine

p. 31 


\section{Chapter I: Introduction}

Immediately following the attacks of September 11, 2001, a palpable change occurred in the political and cultural temperament of the United States, almost as though the population was under the influence of some powerful drug. This caused many Americans to become bellicose and confrontational, to purchase enormous flags which were ubiquitously mounted on pickup trucks, office buildings, and porches. There was an unfamiliar tension in the air-people were openly calling for vengeance on whomever had committed these heinous acts.

Watching the twin towers turn to rubble was traumatic and numbing. While living in New York City, I had been in the World Trade Center towers many times, and they had seemed larger-than-life. To watch them fall was shocking. My response to this epochal event was reflective rather than reactionary: why had this happened? I was aware of the ongoing conflict between the United States and many Middle Eastern countries, as well as the American support of numerous authoritarian, theocratic, and dictatorial regimes throughout the region. This event had not happened in a vacuum.

Not unlike the near-instantaneous presumed guilt of Lee Harvey Oswald as the lone gunman in the assassination of President John F. Kennedy, within hours of the attacks on New York and Washington D.C., President Bush inexorably labeled Osama bin Laden as the orchestrator of the attacks. Al Qaeda, he said, was hell-bent on the destruction of our society, of freedom itself. Bin Laden was the enemy: a cunning 
'evildoer' whose minions committed suicide by flying commercial airliners into iconic American landmarks.

From the perspective of the Bush Administration, an act of war had been committed against our great country. This was not a crime perpetrated by nineteen criminals, but a casus belli that would result in the largest military miscalculation in the nation's history. This confounding feat of terrorism—brilliantly planned and almost seamlessly executed — would put in motion a revolutionary foreign policy strategy never imagined in the worst nightmares of its victims. Within this new doctrine, Afghanistan and Iraq were the first on a list of "up to sixty countries" (Podhoretz, 2007, p. 104) considered as potential targets for future U.S. military engagements.

This thesis deals directly with the implications and ramifications of the Bush Doctrine, the rise of American nationalism, and the almost complete lack of recognition or acknowledgement of the relationship between the two. The overarching themes and strategies of the Bush Doctrine fit within the framework of nationalism. In my research on American nationalism, there is a gap in the literature: for proponents of the Bush Doctrine, specifically those supporting the invasion of Iraq, the term 'nationalism' is nearly absent - an interesting paradox. Those who most strongly advocate elements of the Bush Doctrine that fit within the paradigm of American nationalism (preemptive war, absolute sovereignty, and the implications in regard to extraordinary rendition, and torture), are the last to acknowledge or define it as such. Out of 10 pro-Bush Doctrine authors I reviewed, only one identifies himself as a nationalist, while others identify 
themselves with euphemistic titles such as 'neoconservative' and 'paleo-conservative.' Those in opposition to the Bush Doctrine occupy a wider spectrum: eight not using the term 'nationalism,' nine using it. Because of their opposition to the doctrine, none of these authors' principles might be construed as ideologically compatible with nationalist thinking.

Like many Americans, my awareness of nationalism remained virtually nonexistent until my introduction to the topic in a class taught by Harry Anastasiou titled Nationalism and Ethnic Conflict. Based on historical literature and the ongoing dispute over the the island of Cyprus, it focused on the intractable strain of ethnocentric nationalism between Greece and Turkey.

I began to learn more about nationalism from the literature of prominent scholars in the field such as Peter Alter, Michael Ignatieff, Anatol Lieven, and Paul T. McCartney. I cannot say precisely when I began to discern a correlation between the topic I was studying and the foreign policy doctrine introduced by the Bush Administration in the aftermath of September 11, but what I noticed in the United States was a dramatic intensification of American nationalism. As I will examine, the subject matter in the literature fits definitively within the context of the American foreign policy doctrine instituted by the Bush Administration in the post-9/11 era. Furthermore, the literature I examined whose authors were proponents of the Bush Doctrine and failed to address the topic of nationalism were inadvertently describing the phenomenon. Similarly, those 
authors who expressed opposition to the Bush Doctrine and overlooked the significance of nationalism were describing the phenomenon analogously.

Nationalism may be one of the most difficult political and social phenomena to define and explain, but is not difficult to identify. Nationalism has manifested in a variety of genres throughout modern history, and though its precise definition is elusive, nationalism remains an enduring threat to global peace and stability (Alter, 1993). Nationalism is a force that transcends political ideology, although it is most often identified with the most extreme extensions of political ideology, regardless of their origin (Anastasiou, 2008).

Nationalism manifests in an intensely fervent mindset - elevating the image of the nation to sacrosanctity. Ignatieff, (1993) says, “As a moral ideal, nationalism is an ethic of heroic sacrifice, justifying the use of violence in the defense of one's nation against enemies, internal or external"' (p. 5). The ravages of nationalism and its after-effects continue to echo throughout much of Europe - although the primary goal of the formulation of the European Union was to rid that continent of nationalism's violent tendencies (Anastasiou, 2007). Europe was nearly destroyed by nationalism in World War I and World War II. Adolf Hitler's National Socialist German Worker's Party, and Japan under the leadership of Emperor Hirohito exemplify the most extreme forms of nationalism in modern history. As recently as the 1990s, the Balkans were laid waste by nationalism's iniquitous progeny, ethnic cleansing. To understand nationalism, it is important to illuminate the most common aspects of the phenomenon. 
According to Parenti, (2004):

Nationalistic devotion tends to mimic religious devotion, not only in its intolerance of dissent but in its very forms and belief structure. [Its] ritual symbols, monuments, and hymns; its parchments engrossed with the revealed word; its devotional pledges uttered like prayers; and its commemorative holidays and convocations. (p. 66-67)

In its most primitive form, nationalism advances the idea that the nation is the core of one's identity. It supersedes an individual's sense of self and requires that citizens be willing to die and kill for the nation without hesitation or question. In the case of American nationalism, citizens are taught from an early age to believe that America is the greatest nation on earth, thus introducing the common nationalist belief in the superiority of one's nation - this is often referred to as American exceptionalism. Under normal conditions, American nationalism lies dormant, but when evoked, it becomes a perilous and formidable instrument. Another characteristic of nationalism is the readiness by which it justifies the military option, and the ease in which it moralizes that decision without regard to the consequences of warfare. This is clearly reflected in the words of President George W. Bush, nine days after the 9/11 attacks, when he asserted:

I will not forget this wound to our country or those who inflicted it. I will not yield; I will not rest; I will not relent in waging this struggle for freedom and security for the American people. The course of this conflict is not known, yet its outcome is certain. Freedom and fear, justice and cruelty, have always been at war, and we know that God is not neutral between them (George W. Bush, "Address to the Joint Session of the 107th Congress", September 20 2001).

\section{Problem Statement}


This thesis will evaluate perspectives held by advocates, and opponents of the Bush Doctrine, and will attempt to determine as to whether advocates and critics of the Bush Doctrine, in effect, are advocating, and critiquing, respectively, the same phenomenon: American nationalism.

\section{Research Questions}

Is American nationalism a central factor in understanding American foreign policy in the post-9/11 era? Specifically, did nationalism play a central role in the run-up to the Iraq War, and to the 'War on Terror' in general?

\section{Hypotheses}

1. Advocates of the Bush Doctrine in the post-September 11 era are speaking from a nationalist perspective, although they do not make reference to American nationalism.

2. Opponents of the Bush Doctrine who make no reference to American nationalism are, in effect, critiquing its influence on foreign policy.

3. Understanding nationalism as a phenomenon will provide critical insight into America's approach to international issues, security challenges, and terrorism in the post-9/11 era. 


\section{Chapter II: Methodology}

The methodology within this thesis is qualitative, subjecting authors and documents researched to scrutiny using content analysis. This strategy of inquiry is situated in the theoretical framework of informing conflict analysis and resolution. The qualitative methodology compares and contrasts dominant themes that emerge from the texts of the authors concerned, and the content of relevant policy documents as they illuminate the research question.

The literature I chose to review came from two perspectives: the first being material from advocates of the Bush Administration, the Bush Doctrine, and the invasion of Iraq. This included the examination of neoconservative ideology, which encompassed an unapologetic eagerness to engage in preemptive war; the disdain of international institutions; the perceived universality of American values (American Exceptionalism) including the willingness to sacrifice the lives of others. The first group of authors I chose to examine were prominent intellectuals advocating the neoconservative perspective. This 
group were predominantly visible on conservative media outlets, including talk radio, cable news networks, newspaper editorial sections, and as spokespeople and proponents of and for the Bush Administration and the Bush Doctrine during the pre-invasion, invasion, and post-invasion of Iraq. From this perspective I gathered a direct correlation between neoconservatism and American nationalism.

The second perspective I examined was from those who opposed the Bush Doctrine, and thus, the invasion of Iraq. This group saw American preemption as dangerous and unprecedented; saw the disdain for international treaties and institutions as reckless; viewed American Exceptionalism as dystopian — maintaining the loss of life suffered in an offensive — and perhaps illegal war — as unacceptable under any circumstances. The second group of authors I chose to examine were prominent intellectuals advocating a perspective of conflict analysis and resolution; thus, an anti-war perspective. These authors were openly critical of the Bush Administration and the Bush Doctrine, but were nearly invisible in the media. Many were academics, and although widely published, did not have the same opportunity to express their viewpoints in the public realm of talk radio, cable television, newspaper editorials, and spokespeople opposing the Iraq invasion. They were, in effect advocating an anti-nationalist perspective.

Chronologically speaking, this study will cover the period between September 11, 2001 and January 19th, 2009 (President George W. Bush's final day in office) and will 
review the strategic implications put forth by prominent authors and numerous foreign policy documents from that period. It examines the mission statement, selected documents, and letters of the Project for a New American Century (PNAC), an influential neoconservative think tank whose membership included many who were members of the Bush Administration. In my review of these foreign policy documents, mission statements, speeches, and letters, I identify language and actions relevant to an examination of American nationalism and examine the characteristics with which the Bush Administration's actions align with and utilize a lexicon of nationalism.

This research and analysis addresses the specific policies included within the documents. The primary source material examined in the research includes:

- a letter addressed to President Bill Clinton from the Project for a New American Century (PNAC), January 1998;

- mission statement of the PNAC;

- presidential and cabinet-level speeches;

- documents from the White House, Justice Department, Department of Defense, State Department, and other governmental departments relating to foreign policy issues and policies related to 'enhanced interrogation' techniques;

- the 2001 Quadrennial Defense Review (QDR);

- the 2002 National Security Strategy of The United States (NSS);

- the 2001 Nuclear Posture Review (NPR);

- the 2002 Congressional Research Service's Report to Congress on The Nuclear Posture Review;

- the International Committee of The Red Cross Report on The Treatment of Fourteen Detainees, (2007). 
The literature review examines authors whose perspectives on the Bush Doctrine are diametrically opposed. It will address specific themes that emerged to determine whether or not they are aligned with dominant themes in nationalism. It will include the study of authors who have written on the topics of American militarism and expansionism, and American exceptionalism. It will examine others who have addressed issues of patriotism, super-patriotism, nationalism, and American nationalism, and will explore whether or not proponents of the Bush Doctrine are in effect, advocates of nationalism. Similarly, it will examine whether or not the opponents of the Bush Doctrine are actually critics of nationalism. The literature researched includes excerpts from presidential speeches, and official documents and statements from members of the Bush Administration, books, peer-reviewed articles, newspapers, periodicals, magazine articles, and published writings of relevant think tanks.

The topics and sub-topics covered will include:

- Speeches by the President and members of his administration before, during, and after the invasion of Iraq dealing specifically with 'terrorism' and the threat from Iraq

- Statements by members of the Bush Administration regarding adherence to, or disregard of International Law

- Citations from Project For A New American Century's letter to President Clinton (1998)

- Citations from Project For A New American Century’s "Rebuilding America's Defenses: Statement of Principles" (2000)

- Proponents of the Bush Doctrine who endorse American nationalism

- Authors supporting the Bush Doctrine without mentioning American nationalism 
- Authors opposing the Bush Doctrine who warn of the dangers inherent in American nationalism

- Authors in opposition to the Bush Doctrine who fail to mention American nationalism

- Authors who address nationalism and theories of the phenomenon, both classic and modern, and American nationalism, from the perspective of peace and conflict resolution theory and practice

- Authors opposing the Bush doctrine and American nationalism as inculcating dangerous attitudes toward international peace and cooperation.

When exploring any likely relationship between the Bush Doctrine and American nationalism, it is imperative that the researcher be aware of their own subjective social reality. As such, it is important to note that this study reviews a contemporary phenomenon, and is therefore without the benefit of hindsight and historical distance. In academic circles, little has been written about American nationalism, and although literature on the subject began to surface after September 11, few identified a correlation between nationalism and the Bush Administration's new foreign policy. 


\section{Chapter III: Literature Review}

Americans do not recognize or understand nationalism, and perhaps more importantly, the concept of American exceptionalism which lies at the heart of America's nationalist narrative. Consequently, there is a lack of reflection and awareness of these phenomena and their consequences. If nationalism has influenced American foreign policy, it needs to be both substantiated and examined.

\section{A Profile of Nationalism:}

Nationalism as a phenomenon has been extensively examined from a variety of perspectives, but mostly by non-American, European authors. Smith (1993) proposes that nationalism provides a necessary, binding, and cohesive identity. Conversely, Anastasiou (2009) contends that while a powerful and unifying force, nationalism is a destructive force that nearly destroyed Europe in two world wars and maintains that nationalism was the root cause of a wide range of conflicts throughout modern history.

Anastasiou (2009) and Ignatieff (1993) assert that nationalism played a major role in the deadly and protracted Balkan wars of the 1990s. While nationalism has been a phenomenon that is intractably violent and destructive, while carrying with it an “appealing and ennobling” character-one that appears difficult to resist. In his work, "Encountering Nationalism" (2009), Anastasiou describes the literature on nationalism as being traditionally polarized, but that a different approach might suggest that "advocates 
and critics of nationalism reflect two sides of the same coin" (p. 32). Anastasiou describes the scope of nationalism as:

A powerful historical phenomenon that is defined by the unprecedented moral absolutization of the nation, its freedom, its interest, its community, its identity, and its power, in combination with the derivative presumption that its supreme moral status furnishes thereby "the right" to employ all means, including adversarial and lethal means, in the nation's defense, sustenance, advancement, expanding powers, and alleged "destined" historical realization. (p. 32)

The prevailing summation from experts in the field is that regardless of political, or party affiliations, various iterations of nationalism are strikingly similar: they do not fit into an ideological scope (i.e., right wing vs. left wing). What they do incorporate is a propensity for violence - a predisposition to kill and die for the cause. According to Anastasiou:

As nationalism presumes the nation to be sacred, the taking and offering of human life to its service at critical moments in history is viewed not only as legitimate but as a "moral duty." Hence, according to the nationalist mind, though momentarily inconvenient, the offering and taking of human life for the sake of the nation is ultimately neither a problematic nor a tragic phenomenon but one of "supreme duty" and altruistic "ultimate sacrifice." (2009, p. 35)

Similarly, nationalism has an intrinsically appealing quality which plays on fear and intolerance of others. Additionally, the use of symbols, oaths, and pledges are often employed to test and determine loyalty, and an inclination to idealize mythical images of past and future glory, based on battles fought against intractable and ruthless enemies. Ultimately, an innate suspicion of negotiation, compromise, and diplomacy endures.

\section{Universal Nationalism and American Exceptionalism:}

The concept of American Exceptionalism and Universal Nationalism will be addressed more thoroughly in the next chapter, but it is useful to reference these 
phenomenon as integral parts of the American nationalist paradigm. American

Exceptionalism - universal nationalism — is quite specific in what it espouses. As McCartney, (2004) states:

Embedded in Americans' belief in their nation's universal significance is a sense of mission, which sometimes emerges as a crusading mentality. This sense of destiny also reflects American exceptionalism, the conviction that the United States is qualitatively different from - and better than - other states.

Furthermore, "it has generally been understood to carry for Americans a duty, a peculiar responsibility to lead others and share its self-evidently desirable liberty.” (p. 403)

American Exceptionalism is unique because it poses a theoretical framework that differs from the paradigm of historical nationalism in one every specific way-promoting American values, politics, and culture as a benefit to those it is imposed on. As McCartney notes: "By conceptually merging the U.S. national interest with the improvement of other countries in this way, the idea of American mission allows the United States to enhance its own power on the world stage not by "conquering" other states, but by "liberating" them." (2004, p. 407). The concept of 'liberation' has an appealing quality to Americans who feel the United States is obligated to improve the world in our image as the 'exceptional' nation. As a result of this self-perception of American benevolence, Anastasiou (2009) states: "Since American values are assumed to coincide with the good of humankind, spreading American values is seen as a supreme moral duty toward the rest of the world." (p. 9)

\section{U.S. Foreign Policy in the Post-9/11 Era}


In response to the attacks of September 11, 2001, a wave of hyperpatriotism swept across the nation. Capitalizing on this sentiment, the Bush administration introduced the National Security Strategy of the United States (NSS) in September 2002. A limited number of authors addressed this as American nationalism (Blankley, 2009; Hopkins, 2007; Lieven, 2004; McCartney, 2004). Others, critical of Bush's foreign policy, do not correlate American foreign policy with nationalism (Guerlin, 2006; Gupta, 2008; Kahn, 2004; Owens, 2008). Similarly, the majority of those reviewed authors advocating the administration's policies fail to address the phenomenon of American nationalism (Boggs, 2004; Bolton, 2007; Bush, 2001; Kagan, 2003-2004, 2008; Kaplan \& Kristol, 2003; Podhoretz, 2007).

The literature review addresses dominant themes by authors-both proponents and advocates of the Bush Doctrine - and includes excerpts from presidential speeches and official statements from members of the administration. It incorporates literature from the fields of conflict resolution and peace studies, as well as conflict analysis and resolution. It reviews literature by both advocates and critics of the Bush Doctrine- the former espousing the virtues of American hard power, and the latter, denouncing it as dangerous. It examines literature, documents, and letters from the Project for a New American Century (PNAC), a neoconservative think tank whose membership included primary architects of the Bush Doctrine, many of whom were later appointed to highranking positions within the administration. It also reviews the work of authors critical of the Bush Doctrine who have not explicitly referenced its nationalist ideologies. 
On September 20th, 2001, President George W. Bush outlined the parameters of

America's new foreign policy in a speech delivered to a joint session of Congress:

Great harm has been done to us. We have suffered great loss. And in our grief and anger we have found our mission and our moment. Freedom and fear are at war. The advance of human freedom - the great achievement of our time, and the great hope of every time - now depends on us. Our nation, this generation will lift a dark threat of violence from our people and our future. We will rally the world to this cause by our efforts, by our courage. We will not tire, we will not falter, and we will not fail. (p. 5)

Following the attacks of September 11, and the introduction of the National Security Strategy in September 2002, foreign policy strategies changed profoundly (Boggs, 2004;

Gupta, 2008; Hopkins, 2007; Khan, 2004; McCartney, 2004). The new paradigm of the

Bush Doctrine proposed the following prerogative:

[The National Security Strategy of the United States] ... Will disrupt and destroy terrorist organizations by: defending the United States, the American people, and our interests at home and abroad by identifying and destroying the threat before it reaches our borders. While the United States will constantly strive to enlist the support of the international community, we will not hesitate to act alone, if necessary, to exercise our right of self-defense by acting preemptively against such terrorists, to prevent them from doing harm against our people and our country. (p. 6)

Responding to the public's perception of an ever-present threat of terrorism, the Bush Administration introduced the unprecedented policy of preemptive (or preventive) war.( McCartney, 2004; Owens, 2008). This doctrine expanded U.S. sovereignty and military power beyond national borders, introducing to the world a "struggle against global terrorism" (National Security Strategy, 2002, p. 5).

\section{Dominant Themes of Authors Advocating the Bush Doctrine:}




\section{The Benefits of Preemption}

As was addressed in the last section, a key element of the Bush Doctrine was the proclamation by the president of the right to use military force in a preemptive fashion. As president Bush proclaimed in his commencement speech to West Point graduates June 1, 2003:

Our security will require transforming the military you will lead: a military that must be ready to strike at a moment's notice in any dark corner of the world. And our security will require all Americans to be forward-looking and resolute, to be ready for pre-emptive action when necessary to defend our liberty and to defend our lives" (p. 2).

In the literature written in support of the Bush Doctrine-including Kagan's “The September 12 Paradigm" (2008), Owens' "The Bush Doctrine: Foreign Policy of the Republican Empire" (2008), Of Paradise and Power: America and Europe in the New World Order (Kagan, 2003), The War Over Iraq: Saddam's Tyranny and America's Mission (Kaplan and Kristol, 2003)_preemption was proclaimed as nothing particularly out-of-the-ordinary, and that the Bush Doctrine was far from revolutionary. According to Owens (2008), the most crucial aspects of the Bush Doctrine had been in place since the birth of the nation. The attacks did not transform America's view of its own power, but rather they reinforced it. Kaplan and Kristol note that the Bush Doctrine offered the United States an extraordinary opportunity to expand its power and reach, under the guise of spreading freedom and democracy_enabling the United States to inhabit its proper place in the world. The president clearly stated that overthrowing Saddam Hussein's regime and a subsequent victory in Iraq would set a historic precedent. Even when Iraq 
"becomes a democracy," it will be the first step in accomplishing the much larger goal of gaining a secure foothold in the region and "provid[ing]...guidance and a mission for American foreign policy as a whole" (Kaplan and Kristol, p. 73). Kagan asserts that this policy would be aggressively and unapologetically pursued as an effective and essential tool in the War on Terror. He surmises:

Just at the moment when Europeans...have begun settling into their postmodern paradise and proselytizing for their doctrines of international law and international institutions, Americans have been turning in the other direction, away from the common solidarity with Europe... and back toward a more traditional American policy of independence, toward that uniquely American form of universalistic nationalism. (p. 76)

Kaplan and Kristol suggest that the U.S. views itself as a benevolent 'universal policeman,' and that in a chaotic and unpredictable world, peace and justice must be secured at gunpoint. Within this group of 'hard power' advocates, Kagan is alone in identifying nationalism as a component of the Bush Doctrine.

\section{Hegemonic Aspirations}

The Project for a New American Century's strategy report, Rebuilding America's Defenses: Strategy, Forces and resources for a New Century (2000), frames military power as the ultimate tool for maintaining global hegemony. "At present the United States faces no global [military] rival. America's grand strategy should aim to preserve and extend this advantage as far into the future as possible" (p.i). As Scowcroft (2008), and Kaplan and Kristol (2003) insist, not since Rome has any nation possessed as much influence and power as the United States. Kagan (2003) asserts that the United States is 
unrivaled in global military power and reach. And finally, as the 2002 National Security Strategy puts forth:

The United States possesses unprecedented — and unequaled — strength and influence in the world. Sustained by faith in the principles of liberty, and the value of a free society, this position comes with unparalleled responsibilities, obligations, and opportunities. The great strength of this nation must be used to promote a balance of power that favors freedom. (p. 1)

\section{Perpetual War}

The Bush Doctrine and its policies, as interpreted by Podhoretz in WWIV: The Long Struggle Against Islamofascism (2007), may justifiably lead the United States into prolonged military conflicts and keep the United States at war "as far as the eye can see” (p. 104). In Podhoretz's view, the United States has been at war since the National Security Doctrine was introduced by Harry Truman in 1947:

World War III began in 1947 and ended in 1989, having been fought and won by us under the highly imprecise name of the Cold War. From this it follows that the right name for the war that, as shall be seen, was already being waged against the United States long before 9/11/2001 ... is World War IV. (p. 5)

He contends that the United States is at war against "a monster with two heads" (p. 13), combining a dangerous brew of religious and secular despotism. This force combines the fanaticism of a religion founded in the seventh century with the ideologies of the cold war; and fused with the technology and weaponry of the twenty-first century. He unequivocally endorses the doctrine of preemption, writing that "to move into the future 
[means] to substitute preemption for deterrence and to rely on America's military might rather than the 'soft power' represented by the $\mathrm{UN}$ and the other relics of World War III” (2007, p. 104). Where did this reliance on 'hard power' originate? In The Forty Years War: The Rise and Fall of the Neocons, from Nixon to Obama (2009), Colodny and Shachtman write that the insistence of military action (or the threat thereof) originates from the fear of "provocative weakness" (p. 3). In this context, weakness itself is not simply provocative - the mere perception of weakness is perilous. The authors write that this mindset began with a man whose influence has been near-universal in neoconservative circles:

Although the public had no awareness of Fritz Kraemer, he had influenced generals, service secretaries, secretaries of defense, and secretaries of state since the late 1940's. It was Kraemer who had coined the term "provocative weakness." That concept, which reflected his militaristic approach to foreign policy, along with other Kraemer tenets such as his rejection of diplomacy and his emphasis on morality as a guide for policy, made Kraemer the unacknowledged godfather of the George W. Bush Administration's relating the United States to the rest of the world... [Bush shared] Kraemer's basal distrust of international organizations such as the United Nations...His preference for elite rule... His belief in the need for the United States to spread democracy, to his championing of Christianity. (p. 3-4)

President Bush shared these 'Kraemerite' beliefs, as did nearly every member of his administration, specifically those who had been (or were current) members of the Project for a New American Century.

\section{Sovereignty as an Ineluctable Right}

The protagonists of the Bush Doctrine - the Project for a New American Century (1998, 2000), Kaplan and Kristol (2003), and Bolton (2007) — proclaim that the 
sovereignty of the United States is ineluctable: it cannot be influenced or affected by other nations or outside organizations (such as the United Nations, the European Union, or the International Criminal Court). A letter dated January 26th, 1998 and addressed to President Bill Clinton by members of PNAC states:

We believe the U.S. has the authority under existing UN resolutions to take the necessary steps, including military steps, to protect our vital interests in the Gulf. In any case, American policy cannot continue to be crippled by a misguided insistence on unanimity in the UN Security Council. (Abrams, et al., 1998, p. 2)

Although this letter was written long before September 11, many of its signatories include the architects of the Bush Doctrine, including Elliott Abrams, Richard L. Armitage, John Bolton, Robert Kagan, William Kristol, Donald Rumsfeld, Richard Perle, and Paul Wolfowitz. As Kaplan and Kristol (2003) surmise, "It is exceedingly strange to view the United Nations as a higher moral authority than the United States. The UN after all, is simply a collection of sovereign states... A tyranny is as welcome as a democracy" (p. 91).

\section{The United Nations as an Obstacle}

After refusing to permit a final vote on his nomination by Senate democrats because of a "confrontational brand of conservatism" (VandeHei \& Colum, 2005, p. 1), President Bush installed John Bolton as Ambassador to the United Nations for a 17 month recess-appointment. In Bolton's Surrender Is Not An Option: Defending America at the United Nations and Abroad (2007), he maintains that the national interest of the United States is promoted and maintained most effectively by withdrawing from 
responsibilities mandated by the United Nations and other international organizations. In his view, the sovereignty of the United States trumped any outside authority. While acting as Undersecretary of State for Arms Control and International Security Affairs in the Bush Administration (before his appointment to the United Nations), he began the process of eliminating international treaties:

I was not involved in the decision to reject the Kyoto Protocol on global warming, but I was active in many others that the True Believers characterized as Bush's "unilateralist" approach. In fact, we were simply rejecting inferior policies and agreements, and replacing them with greater American independence and fewer unnecessary restraints. It was just that there were so many unnecessary constraints that everywhere we turned there was something to eliminate. (p. 84)

He boasts of his ability to influence (and simultaneously repudiate) the United Nations:

In the case of the ABM Treaty (Anti-Ballistic Missile Treaty of 1972), the CTBT (Comprehensive Test Ban Treaty), the small-arms/light weapons issue, and the ICC (International Criminal Court), the True Believers, both inside the career bureaucracy and outside it, flatly disagreed with the Bush Administration's position and worked to reverse it. With persistence and hard work, President Bush's position prevailed. The ABM Treaty is dead, the CTBT Treaty will never come into force, the small-arms/light weapons issue has been put its proper place, and the United States has kept its independence from the ICC. (p. 100)

There are several consistent themes throughout the literature on the topic of the Bush Doctrine and U.S. foreign policy in the post-9/11 era. Proponents of the doctrine argue that the use of preemptive military force is not only acceptable, but is essential in maintaining national security (Kagan, et al.). Preemptive force is a vital component in the battle against "Islamofascism" (Podhoretz, 2007). This mentality both stems from and reinforces the belief that the sovereignty of the United States is absolute. As such, the 
United States could not adhere to treaties such as the ABM, CTBT, or ICC, as they would jeopardize American sovereignty (Bolton, 2007).

\section{American Nationalism: The Sum of All Parts}

In American Grit: What it Will Take to Survive and Win in the 21st Century (2009), Tony Blankley openly proclaims his worldview as that of an American nationalist, and promotes similar perspectives as advocates of the Bush Doctrine, but goes much farther in his specificity of how nationalism should influence Americans. Blankley asserts that: "The best interest of the nation requires us to consider rolling back our attachment to personal rights and entitlements, an attachment that has become selfindulgent” (p. 8). Blankly promotes military spending over health care, the return of national conscription, and, "personal sacrifice for the good of the country" (p. 8). Without mentioning the terms specifically, Blankley sums up American Exceptionalism and 'Universal' Nationalism as such: "America was and remains the last best hope of mankind. So long as America is strong and free, the upward trajectory of man is still possible - and indeed is still underway. Without America to give hope to all of man's nobler instincts, what a cruel, nasty place the world would be" $(2009$, p. 6).

According to proponents of the Bush Doctrine, The United States, as the sole remaining world superpower, is obligated to expand its reach and influence globally. Although the world is seen as a precarious place, America's reluctance to abide by international law is simply viewed as a way for the U.S. to be more independent in decision making —eliminating the necessity of cumbersome bureaucracies. In times of 
crisis, it is imperative that the United States act on its own. As is asserted by the authors reviewed in this section, expanding American power throughout the world will improve the national security of the United States and its allies, and will ultimately, enhance the human condition. By maintaining the categorical prerogative to engage in preemptive war, the United States can achieve its ultimate goal of unchallenged expansion and military dominance, while simultaneously spreading American freedom and democracy throughout the Middle East - these phenomena can be referenced as American Exceptionalism, or Universal Nationalism.

The Project for a New American Century (PNAC) played a preeminent role in the development of the Bush Doctrine. Preemptive war, and the theoretical concept of perpetual war is prevalent in the core ideology of this group. Hard power (as opposed to soft power), the complete lack of faith in international institutions, and the impulsive nature of 'spreading democracy' are embodied in the fundamental ideology of PNAC. Furthermore, the ideation of perpetual war, and the stalwart insistence on unyielding military strength reflect tendencies endemic in nationalist thinking. This ideology is consistently advanced by proponents of the Bush Doctrine.

Finally, according to authors writing in support of the Bush Doctrine, America's quest must be the unequivocal right to exercise absolute sovereignty (hence, the right to wage preemptive war, ignore international law_including the Geneva Conventions' Ban on Torture and the United Nations in general), and to proceed uninhibited as the world's benevolent hegemon. These are the fundamental principles of American nationalism. 


\section{Dominant Themes of Authors Opposing the Bush Doctrine:}

\section{The Dangers of Preemption}

Just as proponents of the Bush Doctrine advocate aggressive and unilateral foreign policy strategies (Kagan, et al.), opponents of the doctrine-including Bacevich, (2008), Boggs (2004), Brzezinski \& Scowcroft (2008), Gupta (2008), Hopkins (2007), Khan (2004), and McCartney (2004) — view those policies as detrimental to the national security of the United States. Gupta, in "The Doctrine of Pre-emptive Strike: Application and Implications During the Administration of President George W. Bush" (2008), asserts that the Bush Doctrine could have lasting consequences for international diplomacy and security, and add, with no lack of irony, that its aggressive preemptive military stance would commit the United States to "extending democracy, liberty, and security to all regions" (p. 182). Gupta writes that by attacking Iraq, the United States was in clear violation of Article 51 of the Charter of the United Nations, and in the process disregarded fundamental rules of international relations. Historically speaking, preemptive strikes were not a new concept, but it was "the first time it has been declared legal under international customary law” (2008, p. 183). In “The Postmodern Empire: The United States' New Foreign Policy and its Global Challenges”, Khan (2004) asserts that the U.S. foreign policy agenda following September 11 actually imperiled the United States by incorporating these aggressive unilateral positions: using military force as the primary response to (real or perceived) threats; sacrificing the lives of American soldiers 
—and the unfortunate, yet inevitable, 'collateral damage' inflicted upon innocent civilians; and an overt willingness to ignore the consequences of its actions (2004). Khan maintains that twenty-first century U.S. foreign policy strategies are more expansive and aggressive than any previous power would have imagined, let alone attempted:

The war against Iraq was the first step as well as the test case in realizing [the] grand strategy to make the United States a postmodern empire. By declaring a war against terror everywhere, the Bush Administration has itself the opportunity to intervene anywhere militarily and positioned itself to realize this postmodern imperial vision. (p. 273-4)

Bacevich, in The Limits of Power: The End of American Exceptionalism (2008)

concludes that for all the security the United States gained during its Cold War military supremacy, maintaining a strategy of preemption and open-ended conflict throughout the world only increases international strife. "Why is it that when we flex our muscles on behalf of peace and freedom, the world beyond our borders becomes all the more cantankerous and disorderly?” (p. 156)

\section{The Myth of Hegemony}

The prospect of establishing a global footprint was highly touted by the proponents of the Bush Doctrine. Maintaining the ability to initiate military intervention on a universal scale-at a moment's notice became a transformational element in U.S. foreign policy in the post-9/11 era. For opponents of this policy, establishing global military dominance simply increased the probability of new conflicts, leaving the United States strategically emaciated. According to Bacevich, (2008): 
In 2001, in conjunction with the U.S. invasion of Afghanistan, the Bush administration launched far more intensive efforts to carve out a foothold for American power across Central Asia. The purpose... is to increase U.S. influence, especially over regional security establishments, facilitating access to the region by U.S. forces and thereby laying the groundwork for future interventions. (p. 49)

In this context, American hegemony can be viewed from two perspectives.

Advocates of the Bush Doctrine saw it as benevolent—-something the United States was destined to accomplish and morally obligated to fulfill. This approach maintained a devout unwillingness to embrace international, non-governmental organizations, and nations who did not adhere to the status quo determined by the United States. This was exemplified by the invasion and occupation of Iraq, where American audacity and solipsism led to a violent and intractable nationalistic insurgency. Conversely, opponents of the doctrine saw America's successful role through a completely different lens-one integrated with the international community, international organizations, and a strict adherence to international law, as opposed to dictating its own agenda (i.e., either 'with us or against us').

\section{In America and the World: Conversations on the Future of American Foreign} Policy (2008), Zbigniew Brzezinski (former National Security Advisor to President Jimmy Carter, 1977-81) asserts, once the United States begins to disengage from its role (as occupier of Iraq), coupled with "a regional effort in which we'll be engaged together with others about creating stability around Iraq, we will in fact be assuming a continued roll, no longer so heavily reliant on military power, but an approach designed to rehabilitate, to reestablish, to consolidate, to stabilize, and to reassure" (p. 45). 
Bachevich and Brzezinski each address the importance of the United States assuming a more inclusive roll with international organizations, and stress the importance of engaging others in dialogue - combined with efforts aimed at increasing informationsharing and promoting the roll of America as less dependent on military might to ameliorate international disputes. This image of America as cooperative and malleable goes strongly against the nationalist narrative, which insists on complete independence from international organizations, and maintains an indelible resistance to outside 'interference.'

\section{Perpetual War: Perilous and Unsustainable}

While asserting perpetual war to be a necessary, if not somehow desirable instrument in the War on Terror, proponents of the Bush Doctrine summarily dismissed the potentially overwhelming consequences of their actions: the ends justified the means. Opponents, on the other hand, clearly maintained the position that establishing a permanent war-footing would burden the country with battle-related injuries, casualties in the thousands, and staggering economic costs-leading the nation to potential bankruptcy. Bacevich (2008) argues:

Given what the pursuit of American imperial ambitions in the Greater Middle East has actually produced — not simply since $9 / 11$ but over the course of several decades - why would the United States persist in such a strategy? Why not pursue more realistic and affordable objectives, abandoning plans to "liberate" (that is, control) The Islamic world — and then figure U.S. forces accordingly? ... Rather than transforming the armed forces of the United States into an imperial constabulary, the imperative of the moment is to examine the possibility of devising a non-imperial foreign policy. (p. 143) 
Stretching the economic and moral fiber of a nation to fit an agenda based primarily on militarism has far-reaching implications: such actions have proven themselves unsustainable throughout history, and the United States is no acceptation to the rule. According to Boggs (2004):

As the cycle of militarism and terrorism intensifies - as the world moves evercloser to barbarism - the very premise of warfare as a method for advancing national goals has become bankrupt, irrational, for reasons having less to do with democracy or worldwide diffusion of liberal values than the brutal nature of contemporary war itself. We stand at a juncture where large-scale military action tends to aggravate national, religious, and other conflicts, a point doubly applicable to the lone superpower as it takes measures to secure global domination. (p. 279)

\section{Sovereignty Versus International Law and the United Nations}

In Interventions: A Life in War and Peace (2012), former United Nations

Secretary-General Kofi Annan goes much further in his criticism of the Bush

Administration. He asserted that by taking unilateral action and disregarding the United Nations' mandate of a second Security Council Resolution in addition to Resolution 1441

(for approval to use military force against Iraq) the United States and Great Britain acted illegally. The Bush Administration was not in the position to take action against Iraq if Saddam Hussein did not comply with the UN resolutions - that determination could be made only by the United Nations:

The [UN Security] Council itself stated that it would be the judge of whether Saddam was not honoring his obligations and would therefore face serious consequences. And this is why a second resolution was absolutely necessary. It was up to the Council to first determine whether Saddam was in compliance or not. And it was then, separately, up to the Council to determine what the serious 
consequences would be if he wasn't. It wasn't up to two member states [The United States and Great Britain] to take the law into their own hands. (p. 364)

To Annan, the invasion of Iraq was disastrous, as was everything surrounding it: the failure of post-war planning and reconstruction, the inability to recognize or acknowledge the consequences of a highly volatile sectarian divide between Sunni minority and Shia majority, and the dissolution of the Iraq military, resulting in fertile ground for an armed insurgency (leading to the decade-long civil war). Annan stresses the importance of lessons learned from the Iraq experience:

It is equally essential that the folly of the Iraq War, with the resulting calamity for the people of the country and the broader region, does not doom forever intervention when action is endorsed by the Security Council, a humanitarian crisis is urgent, and the cause is just and legitimate. In the case of the Iraq War, the Security Council resolution cited by the United States and United Kingdom as basis for their actions could just as easily have been used in the opposite case. (2012, p. 363-364)

Annan concludes that in its assumed role of the world's sole superpower, the United States ignored the opinion of UN Security Council and chose to "enter into a war that could not be justified under the [UN] charter" (p. 365).

As Andrew Bacevich (2008) maintains, less-powerful nations were coerced by the sheer power of the United States. Going up against the world's only superpower by following heretofore unchallenged international protocol could be perilous:

After 9/11, President Bush abandoned this approach [negotiation]. Certain that American power had become irresistible, he showed little interest in seeking concurrence. Instead, he issued demands. No president had ever told so many governments what they "must" do with such unvarnished insistence. Bush obliged nations to choose: They could align themselves with the United States, or they would find themselves pitted against the world's only super power. (p. 175) 
Opponents of the Bush Doctrine hold a strong belief that a national security agenda based on militarism - including unilateralism, preemptive war and perpetual war —is not only morally and financially unsustainable, but will lead to ethnic, religious, and nationalist unrest, and the unpredictable phenomenon of 'blowback' in countries the United States invades or occupies. While these authors rebuff the logic of the Bush Doctrine and expose its inherent flaws as counterproductive in any region in which it is implemented, several fail to identify it as a narrative built from the framework of American nationalism. According to Kofi Anon, America was in direct violation of international law when it invaded Iraq. The wider consequences of the invasion have, and will continue to result in an array of humanitarian crises, including sectarian and ethnic violence, civil war, and an increase in misplaced, imprisoned, disappeared and refugee populations. From authors reviewed in this section, and from the perspective of peace studies and conflict resolution, these observations portend a grim future for Iraq, and other regions affected by the Unites States' invasion.

The table below illustrates dominant themes addressed in the literature review, and exemplifies the perspectives of advocates of the Bush Doctrine versus those in opposition—and the ramifications of its implementation on future U.S foreign policy. 
Table 1: Dominant Themes of Proponents and Opponents of the Bush Doctrine

\begin{tabular}{|c|c|c|c|}
\hline Dominant Themes & $\begin{array}{l}\text { Authors (proponents } \\
\text { of Bush Doctrine) }\end{array}$ & Dominant Themes & $\begin{array}{l}\text { Authors (Opponents } \\
\text { of the Bush Doctrine }\end{array}$ \\
\hline $\begin{array}{l}\text { The Right of } \\
\text { Preemption }\end{array}$ & $\begin{array}{l}\text { Blankley; Bolton; } \\
\text { Bush (speech at } \\
\text { West Point); Kagan } \\
\text { (2003, 2008); Kaplan } \\
\text { and Kristol;The } \\
\text { National Security } \\
\text { Strategy of the } \\
\text { United States (NSS) } \\
\text { (2002); Project For A } \\
\text { New American } \\
\text { Century (PNAC); The } \\
\text { Quadrennial } \\
\text { Defense Review } \\
\text { (QDR) (2001). }\end{array}$ & $\begin{array}{l}\text { The Dangers of } \\
\text { Preemption }\end{array}$ & $\begin{array}{l}\text { Bacevich; Boggs; } \\
\text { Brzezinski and } \\
\text { Scowcroft; Gupta; } \\
\text { Hopkins; Kahn; } \\
\text { McCartney }\end{array}$ \\
\hline $\begin{array}{l}\text { Hegemonic } \\
\text { Aspirations }\end{array}$ & $\begin{array}{l}\text { Blankley; Kagan; } \\
\text { Kaplan and Kristol; } \\
\text { PNAC; NSS (2002). }\end{array}$ & $\begin{array}{l}\text { The Myth of } \\
\text { Hegemony; } \\
\text { Hegemony as } \\
\text { Dangerous and } \\
\text { Unsustainable }\end{array}$ & $\begin{array}{l}\text { Bacevich; Brzezinski } \\
\text { and Scowcroft; }\end{array}$ \\
\hline Perpetual War & $\begin{array}{l}\text { Blankley; Kagan; } \\
\text { Podhoretz; PNAC. }\end{array}$ & $\begin{array}{l}\text { Perpetual War: } \\
\text { Dangerous and } \\
\text { Unsustainable }\end{array}$ & $\begin{array}{l}\text { Annan; Bacevich; } \\
\text { Boggs }\end{array}$ \\
\hline $\begin{array}{l}\text { Absolute } \\
\text { Sovereignty versus } \\
\text { The United Nations } \\
\text { and International } \\
\text { Law }\end{array}$ & $\begin{array}{l}\text { Abrams, et al; } \\
\text { Blankley; Bolton; } \\
\text { Kagan; Kaplan and } \\
\text { Kristol; NSS (2002); } \\
\text { PNAC. }\end{array}$ & $\begin{array}{l}\text { Sovereignty in the } \\
\text { Framework of } \\
\text { International Law } \\
\text { and the United } \\
\text { Nations }\end{array}$ & Annan; Bacevich \\
\hline
\end{tabular}

In summary, the dominant themes addressed in the literature review are recurrent

in both historical nationalist movements, and in twenty-first century American

nationalism, as is exemplified in the Bush Doctrine. The forthcoming analysis will

address the problem statement, illustrating that the majority of proponents, and many of

the opponents of the Bush Doctrine, are in effect, advocating and critiquing American

nationalism without referring to it directly. The analysis will also address the hypotheses, 
and will demonstrate that proponents of the Bush Doctrine are actually advocating nationalism as beneficial, while opponents of the doctrine who do not address it as such, are actually speaking against nationalism. Similarly, those who oppose the doctrine and address nationalism specifically, warn of its inherent danger to international peace and stability. The analysis will theorize that approaching nationalism from an analytical perspective — and understanding it as a dangerous phenomenon — may provide greater insight into the direction of future American foreign policy. 


\section{Chapter IV: Analysis and Discussion}

This section will engage in a comparative contrast between themes addressed in the literature review and the implications derived from primary source material used in the research. The analysis will address the problem statement and the three hypotheses this thesis is based on. I will reference sources that have not recognized or identified the Bush Doctrine as fitting within a nationalist paradigm, as well as those which have identified this relationship. I propose that themes addressed by proponents and critics of the Bush Doctrine are operating within the parameters of nationalism, and although the Bush Doctrine encompasses a wide range of nationalist tenets, it is seldom addressed accordingly.

\section{Theories of Nationalism: A Historical Perspective}

In Peace and Conflict Studies, $2^{\text {nd }}$ Edition (2009), Barash and Webel identify nationalism as "one of the most powerful forces of modern times" (p. 138). They propose that nationalist movements contain similar components, regardless of the political ideology of the 'protagonists':

[There is] a strong tendency to confer unity by establishing national symbols shared by many persons, regardless of their ethnic identity. National flags, heroes, myths and anthems all have a remarkable hold over most people, and virtually all nations seek to inculcate recognition and respect for such symbols, typically requiring oaths, pledges, or other specific acts of allegiance. (p. 128)

Another aspect of nationalism is addressed in Levinger and Lytle's 2001 article

"Myth and Mobilization: The Triadic Structure of Nationalist Rhetoric." In their 
description of the nationalist mindset, they hypothesize a formula that points to a triadic structure of reality consistent in all nationalist movements - regardless of their political and ideological affiliations:

The triadic structure creates symbolic oppositions through a series of loss and recovery. The binary oppositions emphasize the disjuncture between the ideal condition and the current situation. More severe or multiple losses require greater action to re-establish the nation's status. (p. 188)

The nationalist worldview described by the authors has three key components: that the past is glorious and something to be revered; the present is unstable (the work of sinister forces, both domestic and foreign, operating against the nation); and that the future is utopian, in which the nation will rise above the challenges of the present-day and recapture some (real or imagined) past glory. This struggle against perceived national decay is the key factor in mobilizing nationalist movements, and military bellicosity is at the least, nationalist rhetoric.

\section{Neoconservatism: The Gateway to American Nationalism}

The neoconservative movement was founded by Irving Kristol in the early 1970s. Adherents to this movement were reproachful of the socio-economic 'New Deal' policies of President Franklin Delano Roosevelt and economist John Maynard Keynes, and saw weakness in the conciliatory foreign policies implemented by Presidents John F. Kennedy, Lyndon Johnson, and (most notably) Richard Nixon. These new conservatives were virulently anti-communist, advocated for small government, viewed diplomacy as a waste of time and energy, and believed that a powerful military was the cornerstone of a 
successful U.S. foreign policy. The neoconservatives were infuriated by Nixon's conciliatory gestures toward China, resented his willingness to achieve détente with Russia, and vehemently opposed attempts to negotiate the end of the Vietnam War (Colodny \& Shachtman, 2009).

After Nixon's humiliating resignation in 1973, neoconservatism began to influence the architecture and direction of economic and foreign policy, and continued to do so over the next thirty years. It was these neoconservatives (or neocons) that conceived of, developed, and implemented the hard-line unilateral foreign policy that became known as the Bush Doctrine (Project For A New American Century, 2000). As I will demonstrate, dominant themes in the Bush Doctrine were rooted in the stringent worldview and ideology of neoconservatism. This revolutionary strategy proclaimed the unequivocal right to engage in preemptive war (deeming perpetual war as a realistic probability); believed in absolute sovereignty_overtly ignoring and dismissing international institutions and international law; and envisioned unilateral military action as a necessary tool in the global war on terrorism. This worldview fits definitively within the general paradigm of nationalism.

\section{A Launching Pad for Neoconservative Thought}

Founded in 1973, the Heritage Foundation became a critical hub of neoconservative thought, shaping a generation of future government, military, and civilian leaders. Its founders and financial backers included a surfeit of prominent 
contemporary figures - a veritable who's-who of architects of American economic and foreign policy through the 1970s, 1980s, and 1990s. Some notable members include:

- Tony Blankley, policy analyst and speechwriter for Ronald Regan and former press secretary for Newt Gingrich during his tenure as Speaker of the House;

- L. Paul Bremmer, Administrator of the Coalition Provisional Authority in Iraq, 2003-2004;

- Paul Weyrich, conservative activist, co-founder of the American Heritage Foundation and the American Legislative Exchange Council.

\section{The Cornerstone of U.S. Foreign Policy}

Although the Heritage Foundation was one of many neoconservative think tanks of the 1970s, its influence was especially far-reaching, having spawned many likeminded institutions. The Heritage Foundation's membership contained many highlyinfluential people, and its progeny, the Project for a New American Century (PNAC), established itself as the instrumental organization developing hard-line American foreign policy . Founded in 1997 by Robert Kagan and William Kristol, PNAC's long-term goals were specific, and its influence was global. Vice President Dick Cheney's pivotal role as founding member of PNAC profoundly impacted future U.S. foreign policy. Throughout the 1990s, the ideology of PNAC gained momentum in neoconservative circles whose protagonists feared that the United States was losing its global military advantage due to the Clinton Administration's budget cuts to the Department of Defense. "Without a wellconceived defense policy and an appropriate increase in defense spending, the United 
States has been letting its ability to take full advantage of the remarkable strategic opportunity at hand slip away" (PNAC 2000, p. ii). This perception of American weakness only strengthened the resolve of PNAC members. They saw their rise to power (and the implementation of this new, revolutionary foreign policy strategy) as essential to the survival of the United States as the sole global superpower. The focal point of PNAC's foreign policy strategy in the late 1990s was Saddam Hussein and Iraq. PNAC members sent a letter to President Clinton in 1998 addressing the need for regime change in Iraq, arguing that weapons inspections were insufficient to contain Saddam Hussein:

American policy cannot continue to be crippled by a misguided insistence on unanimity in the UN Security Council. We urge you to act decisively. If you act now to end the threat of weapons of mass destruction against the U.S. or its allies, you will be acting in the most fundamental national security interests of the country. If we accept a course of weakness and drift, we put our interests and our future at risk. (p. 2)

Throughout this period, the yet-to-be-named Bush Doctrine existed as a zealous ideological proposition - too radical to be viable in mainstream policy circles. One specific proclamation in "Rebuilding America's Defenses" was particularly disturbing: the premise that in order to implement these highly unorthodox policies "...the process of transformation, even if it brings revolutionary change, is likely to be a long one, absent some catastrophic and catalyzing event—like a new Pearl Harbor" (PNAC 2000, p. 51).

On September 11, 2001, the implausibility of this philosophy vanished with the destruction of the World Trade Center. That morning, the architects of the Bush Doctrine seized the unprecedented opportunity to achieve their vision of the United States as the 
single unchallengeable hegemonic power-militarily, economically, and culturally—in the world.

\section{The Nationalist Paradigm}

Upon its release in September 2002, the National Security Strategy (NSS) of the United States shifted U.S. foreign policy dramatically to the right. The Bush Doctrine's aggressively unilateral, preemptive stance reflected some of the indicators of what Peter Alter, in Nationalism (1994) has defined as 'integral nationalism.' It is important to avoid a direct comparison to Alter's definition (which he used to define Nazism); however, it is relevant to make note of the disturbing similarities that exist between these incarnations of nationalism:

Radical; extreme; militant; aggressive; expansionist; derivative; right wing; reactionary; excessive... The nation that proves itself as the strongest and fittest in a hostile and competing world shall gain the upper hand and ultimately survive. Exponents of integral nationalism are prepared unscrupulously to assert the interests of their own nation at the expense of others. What is now 'ethical' and morally justified is whatever serves the nation and its power; for that purpose injustice, even crime, is acceptable. (p. 26-27)

The most common theme in the nationalist framework is that the interest of the nation comes before all-else, regardless of precedent. As will be discussed later, the implications and consequences resulting from the open disregard for international law are numerous.

Herein lies the irony of nationalism: those who espouse it view their own perspective as unique. The nationalist worldview is totalitarian and does not tolerate challenges to its principles. Historically, nationalism is inherently conservative, and not 
democratic in nature; the nationalist mind is suspicious of 'others' and is inherently narcissistic. As Anastasiou states:

The narcissism of nationalism sustains blindness to the fact that it shares a strong resemblance to the nationalism of other groups and countries, including and often especially to the nationalism of enemy groups or countries. It suppresses acknowledgement of the fact that while nationalisms may differ in the details of their content, they all share the same template, in that they see their own nation as unique, exceptional, set apart, transcendent and sacred. $(2008$, p. 9)

The American nationalist however, espouses freedom and democracy as the overarching tenets of the phenomenon (often referred to as American Exceptionalism, or Universal Nationalism). In the mind of the American nationalist, American values are universal, and therefore, beneficial to all. The United States military is the fulcrum in spreading these universal values: hence, the virtues of American Exceptionalism are equated with freedom and democracy, even if imposed by force. According to Anastasiou, (2009):

From the perspective of American nationalism, US hegemony in the world thus appears as benevolent, as America's gracious gift to the world, as America's good will toward the world. The presumption of exceptionalism thus renders unilateral military action not only practically justified but morally required in that it is undertaken in the name of universal values, which the nation allegedly embodies. (p. 19)

American Exceptionalism/Universal Nationalism, as put forth by its adherents, encompasses the following paradigm: American exceptionalism-universal nationalism —implicitly promotes the American national interest, lays a strong framework for future global interests, is inherently justified by the nation's proclaimed highest values, and, 
justifies the absence of restrictions on military force and preemptive war. This is the overarching foundation of the Bush Doctrine.

The 2002 National Security Strategy transformed America's foreign policy into the most unilateral in its history; the most conspicuous element being the declaration of the right to preemptively invade any country at any time, exclusively ordained and executed by the president of the United States. Much of the 2002 NSS had been developed in two other Defense Department policy documents - the Nuclear Posture Review (NPR) of 2001 and the Quadrennial Defense Review (QDR) of 2001—both heavily influenced by policy specialists from PNAC. Hence, the strategies put forth in the 2002 NSS had been developed long before the events of 9/11:

U.S. Forces must maintain the capability at the direction of the President to impose the will of the United States and its coalition partners on any adversaries, including states, or non-state entities. Such a decisive defeat could include changing the regime of an adversary state or occupation of foreign territory until U.S. strategic objectives are met. (Quadrennial Defense Review, 2001, p. 13)

According to the Center for Media and Democracy (2009), throughout its tenure in the White House, the Bush Administration included twenty-nine members of PNAC, comprising an array of Cabinet members, department heads, and military advisors. Outside of the administration, PNAC members - all strong proponents of the Bush Doctrine - included prominent newspaper editorialists, conservative intellectuals, and pundits for popular cable news networks, all of whom advocated resolutely for the 2003 invasion of Iraq. The neoconservative canon holds that American sovereignty is absolute, and prioritized the use of hard power—military might—as the primary cynosure of U.S. 
foreign policy; thus, the unilateral proclamation by the Bush administration to invade Iraq without obtaining a second Resolution by the United Nations, and the open hostility toward any nation who refused to acquiesce to the Unites States:

...PNAC issued the first clear call for preemptive war, an action against a country that had not attacked the United States or its allies but that the PNAC construed as a threat to world stability. Rather, it derived from a purely ideological objective that the neocons had been nurturing for a decade. (Colodny \& Shachtman, 2009, p. 385)

Within a wide spectrum of the literature, there is only one author who has described himself as an unabashed American nationalist: Tony Blankley. He served in the Reagan administration, and then “....as press secretary to then-Speaker of the U.S. House of Representatives, Newt Gingrich. In that role, Blankley not only helped create messages which shook the country, [but] also helped create policy..." (Townhall, 2014). In American Grit: What It Will Take to Survive and Win in the Twenty-First Century (2009), Blankley describes his belief system as following suit with those of his contemporaries; however, he asserts a more radical sentiment toward issues such as homeland security and foreign policy — the unilateral, preemptive use of military force, draft reinstatement - as well as a foundational belief in the power of free market economics.

In Blankley's view, the foreign policy strategies of Presidents George H.W. Bush and Bill Clinton were weak on key issues. He viewed the failure to overthrow Saddam Hussein in 1991 as evidence of George H.W. Bush's unwillingness to project American power and influence. Furthermore, he contends, the policies of containment put in place 
by the Clinton Administration made the United States an impotent superpower-one that was slowly but surely losing its hegemonic momentum (2009). He writes, "I still emphatically characterize myself as a conservative. But as one goes through the various zoological categories of the breed...none of them quite captures the driving thrust of my views these days" (p. 5). "Patriotism is love for one's country; nationalism is a call to action," and "nationalism must offer different prescriptions for different times" (p. 6-7). He insists that only a politically, culturally, and militarily dominant America can keep the world free from despotism. "If America falls from its position of dominance, there will be no power on earth to check the advance of tyranny and suffering and despair" (p. 6). He asserts that the Obama Administration, with plans to redistribute wealth, use diplomacy rather than military force, and improve the environment at the expense of American national interests, directly conflict with those of a nationalist, and resolutely maintains:

A nationalist program, such as I propose, seeks to restore America's prosperity, military strength, and sense of patriotism. Above all else, it places the interests of the country first, even though that concept has fallen out of favor in recent years. (p.8)

Finally, Blankley unambiguously asserts his view of United States sovereignty as absolute:

America should always consult closely with its allies on important foreign policy decisions, and use diplomacy to secure the widest possible international support for American actions. But we must vehemently reject demands that would impinge on our sovereignty, even when such demands come from our own allies. The international union that liberals envision is ultimately a utopian pipe dream. The best guarantor of security for the world's democracies and of free international trade is not the United Nations, but the United States military. (2009, p. 146) 
Paul D. McCartney, an opponent of the Bush Doctrine, is one of only five reviewed authors that write of the relevance of nationalism in a review of post-9/11 American foreign policy. McCartney’s “American Nationalism and U.S. Foreign Policy from September 11 to the Iraq War" (2004), addresses nationalism as a foundation of the Bush Doctrine. In McCartney's view, the Bush doctrine changed the global context in which America fits, transforming the world to reflect and duplicate American values and interests. In this way, he writes, the doctrine would prevent the development of an antiAmerican ideology, thus preventing attacks similar to those of September 11, 2001. This "has always been an implicit component of American nationalism" (p. 400). McCartney differentiates American nationalism from ethnocentric nationalism, which flourished violently in Europe during the first half of the twentieth century, and in the Balkans during the last decade of the twentieth century. He goes on to define American foreign policy under the Bush Doctrine is the vehicle on which American nationalism is spread:

National identity and foreign policy are intimately connected in the United States because the former rejects (formally, at least) ethnic or other ascriptive bases of national identity and relies instead on an ideological construction of the nation that insists on the global relevance of the American project. (2004, p. 400)

Pei (2003) expresses a theory on American nationalism, identifying its insidiousness in American culture:

Herein lies the secret of the vitality and durability of American nationalism: The dominance of civic voluntarism - and not state coercion - has made nationalist sentiments more genuine, attractive, and legitimate to the general public. These expressions of American nationalism have become so commonplace that they are virtually imperceptible, except to outsiders. (p. 34) 
McCartney asserts that after the attacks of September 11, America's sense of a collective national consciousness and identity were heightened, increasing nationalist sentiment (perhaps to a level not seen since the Cold War) and that a sense of missionmainly, a crusade against 'evildoers' — was promulgated by the Bush Administration. Furthermore, McCartney ascertains that the 2002 NSS laid the groundwork for aggressive and militaristic foreign policy goals (2004). He also contends that in the eyes of its proponents, the foreign policy of the United States is benevolent:

The American style of foreign policy reflects an ideological and cultural interpretation of both the nation and its place in the world, one that posits that the United States enjoys universal significance because it is an archetype of virtue and the locomotive of human progress. (p. 401)

McCartney interprets American foreign policy as being imbued with a sense of purposeone that need not be explained—and that ultimately, American nationalism "allow[s] Americans to believe that their good intentions lack a selfish dimension and are truly, in some objective way, good for others" (p. 406). McCartney concludes that those three elements combined — heightened national/group identity, a religious mission against an 'other,' and the justification of military force-fit categorically within the framework a nationalist paradigm. Unfortunately, he maintains, "The tragic flaw of the Bush Doctrine is that it draws on a model of American nationalism that has become outdated" (2004, p. 423).

\section{A Missed Opportunity}


In "Demon in the Cellar," (2004) one of the most outspoken critics of American nationalism, Anatol Lieven, identifies American nationalism as a phenomenon that reached unprecedented heights after the events of September 11, 2001. He maintains that after the September 11 attacks, the United States was in a position to "lead an alliance of all the major states — including Muslim ones — against Islamist terrorism, [but chose] instead to pursue policies which divided the west, further alienated the Muslim world, and exposed America itself to increased danger" (p. 1).

From a historical perspective, Lieven identifies the United States as “...in part, simply an old European state which avoided the catastrophes that nationalism brought upon Europe in the twentieth century. Its nationalism thus retains an intensity which Europeans have had kicked out of them by history" (p. 3). He contends that American nationalism is magnified by a solipsistic disinterest in the outside world, resulting in a pronounced disregard of international organizations - including the United Nations and the International Criminal Court—whose influence may impinge on American sovereignty (2004). He argues that any outside organizations that threaten U.S. sovereignty, even remotely, are looked upon with suspicion and contempt:

Nationalism often encourages its proponents to cultivate not only specific hatreds, but hostility to all ideals, goals, movements, laws and institutions, which aim to transcend the nation and speak for the general interests of mankind. These are dubbed empty and naive utopianism, when contrasted with the tough realism of the nationalists. (p. 3) 
Lieven concludes that the attacks of 9/11 gave Americans a sense of victimhood, and that is was this new identity that was the catalyst of a particularly dangerous and bellicose type of American nationalism.

Anastasiou (2009) views American nationalism as fitting into a familiar dynamic, one no different than any other nationalist phenomenon. It is a worldview characterized by an unbending resolve to protect the nation, a refusal to negotiate with a perceived enemy, and a claim of moral superiority over the 'other.' He writes:

American nationalism, particularly in its neoconservative brand, views US national interest and national security in terms of its narcissistic will and its unrivaled strength as the superpower nation. Here too, the invariable status of the nation becomes the supreme arbiter and reference of values, truth and meaning. (p. 35)

Although the evidence of American nationalism in the post-9/11 era is clearly defined by Anastasiou, Lieven, McCartney, Pei, and Parenti, it seems that these authors-critics of the Bush Doctrine - are alone in their theoretical perspective of categorizing the Bush Administration's foreign policy mandate as matching that of a nationalist paradigm.

\section{Nationalism and Absolute Sovereignty: Unilateralism vs. International Law, Human Rights, and International Treaties}

On September 20th, 2002, a revolutionary foreign policy strategy was introduced by the Bush Administration. Coined by neoconservative intellectual Charles Krauthammer as 
the "Bush Doctrine" (2002), the policy's central theme was the assertion of absolute American sovereignty. The Bush Doctrine encompassed a vast array of policy edicts, but the most unconventional and unorthodox was the right to engage in preemptive war. As was described earlier, the strategic and philosophical origins of the Bush Doctrine had been disseminated in the pages of the Project for a New American Century's "Rebuilding America's Defenses: Strategy, Forces and Resources for a New Century" (PNAC, 2000). Not long after, the blueprint for the Bush Doctrine was fleshed out in an array of policy documents formulated by the Department of Defense, including the 2001 Nuclear Posture Review, the 2001 Quadrennial Defense Review, and the 2002 National Security Strategy. And while these were central to the Bush Doctrine, a plethora of documents from other governmental departments and agencies were issued after the events of September 11, 2001. These include the National Military Strategy to Combat Weapons of Mass Destruction (2006), the National Military Strategic Plan For The War on Terrorism (2006), the National Military Strategy For Combating Terrorism (2006), and a host of others dealing with national defense. An excerpt from the 2002 NSS exemplifies this strategy:

In exercising our leadership, we will respect the values, judgment, and interests of our friends and partners. Still, we will be prepared to act apart when our interests and unique responsibilities require. (p. 31)

It is clear that the Bush Administration's foreign policy doctrine would allow little room for the international community to negotiate or use diplomacy as alternatives to unilateral military action by the United States. Unilateral action and a dismissal of 
customary international dialogue became the cornerstone of America's twenty-first century nationalist foreign policy mandate under the presidency of George W. Bush.

Historically, a claim of absolute sovereignty has been propagated as an inexorable tenet of nationalism. From this perspective, it is believed to be the fundamental and irrevocable right of the nation. Absolute sovereignty precludes, usurps, and renders obsolete international treaties, resolutions, arms, and/or weapons agreements, and nullifies the authority of international institutions, non-governmental organizations, and international courts of law (Gonzalez, 2002; Lieven, 2004; Calabrese, 2005; Bush, 2006; Bolton, 2007; Olshansky, 2007; Bacevich, 2008; Owens, 2008). From a nationalist perspective, absolute sovereignty entitles a nation to power that extends well beyond its borders. Broadly incorporated in this interpretation is the self-asserted presumption that a nation-state can justifiably use military force against another to appropriate territory or natural resources, eliminate real or perceived threats posed by ethnic or religious groups and non-state actors, or, as in the case of the 2003 United States invasion of Iraq, to depose a treacherous dictator. In the words of Anatol Lieven (2004), "Nationalism thrives on irrational hatreds, and the portrayal of other nations or ethno-religious groups as irredeemably wicked and hostile" (p. 5).

Notably, as was stipulated in the 2001 Quadrennial Defense Review, plans for regime change via military force, wherever deemed necessary, were choreographed long before the events of September 11: 
U.S. Forces must maintain the capability at the direction of the President to impose the will of the United States and its coalition partners on any adversaries, including states or non-state entities. Such a decisive defeat could include changing the regime of an adversary state or occupation of foreign territory until U.S. strategic objectives are met. (p. 13)

Though the Bush Administration was willing to act unilaterally when confronting international threats, specifically those countries the president had branded "The Axis of Evil” during his 2002 State of the Union Address (Iran, North Korea, and Iraq), the Administration was quick to assure the world a preemptive attack would only be done under the most extreme of circumstances. However, the axiom absolving the United States of obligation to conform to international standards was irrefutably spelled out in the 2002 NSS. It exemplified the administration's presumption of national superiority and rejected any obligation to international protocol. From this point forward, the United States military had a sole purpose:

Defending the United States, the American people, and our interests at home and abroad by identifying and destroying the threat before it reaches our borders. While the United States will constantly strive to enlist the support of the international community, we will not hesitate to act alone, if necessary, to exercise our right of self-defense by acting preemptively. (p. 6)

Ergo, the propensity to identify outside groups as hostile and threatening is manipulated within the context of nationalism to justify the use of violence against those groups, eliminating the necessity of acknowledging responsibility for killing civilians or other innocents in time of conflict, commonly called 'collateral damage.' In an analysis of the U.S. invasion of Iraq in 2003, the following statistics on civilian deaths were determined (from Hicks, M. H.-R., Dardagan, H., Guerrero Serdán, G., Bagnall, P. M., Sloboda, J. A., 
\& Spagat, M. (2011), Violent Deaths of Iraqi Civilians, 2003-2008:

Among the total 92,614 Iraqi civilian deaths from armed violence documented for 2003-2008, Coalition forces caused 12\% (11,516). During the first post-invasion year (March 2003-March 2004), Coalition forces caused 52\% of civilian deaths from armed violence $(7,252)$. $(2011$, p. 2$)$

Can this be justified? From a nationalist perspective, the killing of civilians is viewed as a necessary (albeit unfortunate) part of the process often described as 'liberation.' Parenti (2004), describes this phenomenon:

At the heart of the secular religion of nationalism rests the belief that the messianic nation's existence and its action are so endowed with virtue as to place it beyond the commonplace rules that govern individual morality...The most ruthless violence - insupportable in civil society—is applauded as heroism when performed in the name of the nation... The willingness to kill other human beings in combat is treated not only as morally acceptable but as a heroic measure of one's patriotism. Instead of going to jail, the perpetrators are honored with medals and ceremonial acclaim. (p. 73)

\section{Absolute Sovereignty Unchallenged: International Organizations as a Hindrance}

It became evident that international organizations - including the United Nations, International Criminal Court (ICC), and explicit statutes of the Geneva Conventionsbecame obstacles impeding the Bush Administration's belief in the absolute sovereignty of the United States. The aims of the Bush Doctrine were far-reaching-American hegemony and absolute sovereignty were not simply pieces of a puzzle, they were the cornerstones of the doctrine. These could only be achieved through the utilization of absolute power-militarily, economic, or otherwise. Thus began the inexorable movement toward a vast expansion of executive and military power both domestically and abroad. This included the establishment of the Department of Homeland Security, the 
passing of the USA Patriot Act, the ambiguously-defined 'War on Terror' and its accompanying tactics, the invasion of Afghanistan, and the preemptive and unilateral invasion of Iraq. The final step, motivated by absolute sovereignty came with the appointment of John Bolton as Ambassador to the United Nations. Between 2001 and 2009, the Bush Administration pushed American hegemony to its apex on the world stage - maintaining the incontrovertible right to engage in unilateral, preemptive action, in defiance of the United Nations, and international law.

Not long after White House Counsel Alberto Gonzalez's top secret memo to President Bush proclaimed the Geneva Conventions ban on torture as "quaint" (2002, pg. 2), the Bush Administration set a myriad of alarming precedents under the guise of the 'War on Terror.' Vice President Dick Cheney played a significant role in this, exemplified by his attitude toward torture. Cheney believed that torture was a necessary instrument in the War on Terror, but as an ethical or legal matter, was not worthy of discussion. According to Danner (2014):

Just as he was likely the most important and influential American official in making the decision to withhold the protection of the Geneva Conventions from detainees, Cheney was most likely the most important and influential American when it came to imposing an official government policy of torture. It is quite clear he simply... will not acknowledge that such a policy raises any serious moral or legal questions at all. (p. 52)

Cheney's concerns did not extend beyond his immediate focus: defeating terrorists and their state sponsors at any cost, regardless of the consequences, and even if this approach proved to be illegal. Danner asserts: 
Lack of regret, refusal to reconsider, doesn't alter the train of cause and effect: certainty that decisions were right, no matter how powerful - and the imperturbable perfection of Cheney's certainty is nothing short of dazzlingcannot obscure evidence that they were wrong. Often the sheer unpopularity of a given course seems to offer to Cheney it's own satisfaction, a token of his disinterestedness, as if the lack of political support must serve as a testament to the purity of his motives. (p. 52)

Cheney's uncompromising positions on a plethora of international issues matched those of his colleague, Donald Rumsfeld. Both had an agenda under which there was no room for concession or negotiation. Protecting the national interests of the United States was an all-encompassing quest, and both men were determined to succeed at any cost. As is the case with nationalistically-driven thinking, the nation and its power is above the law: both Cheney and Rumsfeld fit precisely in the nationalist framework.

Before his appointment as Attorney General, White House Counsel Alberto Gonzalez initiated the first of many openly hostile actions by the Administration against established international protocol. In an excerpt from his then-top secret memo to the president in January of 2002, Gonzalez explicitly denounced Article III of the Geneva Conventions - until then considered irrefutable by the international community and definitively established as stare decisis in international law. In a 2002 memorandum to the president, he writes:

On January 18, I advised you that the Department of Justice had issued a formal legal opinion concluding that the Geneva Convention III on the Treatment of Prisoners of War (GPW) does not apply to the conflict with al Qaeda... In my judgment, this new paradigm renders obsolete Geneva's strict limitations on questioning enemy prisoners and renders quaint some of its provisions. 
Under the guidelines of the Bush Doctrine, numerous practices formerly prohibited by the United Nations, the Geneva Conventions, and the United States were now considered acceptable to use; some of these include the following:

- CIA and military prisons, known as 'black sites,' not on American soil (and therefore not subject to the protections granted to detainees by the United States Constitution) such as Guantanamo Bay. "Ghost detainees...refer[ring] to people who [were] held, unregistered, and far from public scrutiny, in these U.S detention facilities" (Olshansky, 2007, p. 11);

- reclassification of prisoners of war as 'enemy combatants.' Under this new classification, any person — foreign national or American citizen — could be arrested and held indefinitely at the whim of the President. (Overturned by the Supreme Court on June 28, 2004, affirming "the right of 'enemy combatants' held at Guantanamo to due process under law flatly rejecting the White House's insistence on unchecked detention of all prisoners in the war on terror...”) (McCoy, A. 2006 p. 147);

- extraordinary rendition: extra-judicial kidnapping: the policy of covertly transporting prisoners to countries where torture was permitted “... The CIA, under President Bush's direct orders, engaged in the extraordinary rendition of some 150 Al Qaeda suspects, sending them to nations whose secret police were, in the view of the State Department, synonymous with torture-Egypt, Jordan, Morocco, Saudi Arabia, Syria, and Pakistan.” (McCoy, A. 2006 p. 117). 
Many of the techniques employed by the CIA and private contractors hired by the U.S. government at these off-shore sites were euphemistically designated as 'enhanced interrogation'. However, it was later determined by the International Red Cross that methods used to extract information from 'enemy combatants' transferred to, and held at Guantanamo Bay, were in effect, torture. In the document, "ICRC Report On The Treatment Of Fourteen 'High Value Detainees' In CIA Custody”, the findings were disturbing:

All of the fourteen [prisoners interviewed in-detention by the ICRC] were subjected to a process of ongoing transfers to places of detention in unknown locations and continuous solitary confinement and incommunicado detention throughout the entire period of their detention. The allegations of ill-treatment of the detainees indicate that, in many cases, the ill-treatment to which they were subjected while held in the CIA program, either singly or in combination, constituted torture. (2007, p. 26)

In a June 7, 2004 report published in the Wall Street Journal titled "Pentagon Report Set Framework For Use of Torture: Security or Legal Factors Could Trump Restrictions, Memo to Rumsfeld Argued," journalist Jess Bravin revealed that the Bush Administration had sought advise from a plethora of legal minds in an ongoing effort to circumvent obstacles preventing the sanctioned use of torture. Regardless of their findings, which contradict the justification for employing such tactics, the lawyers declared that the power of the executive surpassed any jurisdiction:

The working-group report elaborated the Bush Administration's view that the president has virtually unlimited power to wage war as he sees fit, and neither Congress, the courts nor international law can interfere. It concluded that neither the president nor anyone following his instructions was bound by the federal Torture Statute, which makes it a crime for Americans working for the 
government overseas to commit or attempt torture, defined as any act intended to "inflict severe physical or mental pain or suffering." Punishment is up to 20 years imprisonment, or a death sentence or life imprisonment if the victim dies. (p. 5)

The Convention Against Torture (CAT) — was adopted in 1984 by the United Nations General Assembly (Resolutions 39 \& 46). It was enforced on June 26, 1987, having been ratified by twenty countries. It was signed by the United States on April 18, 1988, and ratified by the UN and the U.S. on October 21, 1994. The Convention, as specifically directed to apply to the United States, defines torture as follows:

an act... specifically intended to inflict severe physical or mental pain or suffering and that mental pain or suffering refers to prolonged mental harm caused by or resulting from: (1) the intentional infliction or threatened infliction of severe physical pain or suffering; (2) the administration or application, or threatened administration or application, of mind-altering substances or other procedures calculated to disrupt profoundly the senses or the personality; (3) the threat of imminent death; or (4) the threat that another person will imminently be subjected to death, severe physical pain or suffering, or the administration or application of mind-altering substances or other procedures calculated to disrupt profoundly the senses or the personality. (p. 25)

Furthermore, mere knowledge, or "acquiescence" of torture is also banned by the

Convention. From the Congressional Research Service report on the "U.N. Convention

Against Torture (CAT) Overview and Application to Interrogation Techniques", the

United States demanded specifications of the law that would only apply to them:

As expressed in a U.S. understanding on this point, for a public official to acquiesce to an act of torture, that official must, "prior to the activity constituting torture, have awareness of such activity and thereafter breach his or her legal responsibility to intervene to prevent such activity." U.S. implementing regulations barring the removal of aliens to countries where they would more likely than not face torture reflect this understanding. Subsequent jurisprudence and administrative decisions concerning the removal of aliens to countries where 
they may face torture have recognized that "willful blindness" by officials to torture may constitute "acquiescence". (2009, p. 5-6)

Although the United States insisted on setting its own guidelines to adhere to these laws when they were written and implemented, the Bush administration decided unilaterally, to circumvent them. With little warning, the most powerful nation on earth assumed an unpredictable and belligerent stance, one prone to unilateral policies and decisions, changing the political and military landscape of the world in the process. Correspondingly, three distinct transformations occurred within U.S. foreign policy:

- diplomacy became an obstacle, rather than a vital tool

- institutions and treaties such as the UN, and the Nuclear Test Ban Treaty were summarily ignored by the administration

- the exercise of absolute national sovereignty became unequivocal, and as such, military action became the primary choice when addressing international crises

While Alberto Gonzalez was the first in a line of Cabinet members and appointees to espouse a belief in absolute American sovereignty, it was Secretary of Defense Rumsfeld that blithely summed up the decision of the Bush Administration to remove itself from the jurisdiction of the International Criminal Court, proclaiming defiantly that the risks of abiding by the statutes of the ICC clearly outweighed the benefits. In a written statement addressed to UN Secretary General Kofi Annan on May 6, 2002, Rumsfeld stressed that forcing the United States to comply with international restrictions would create impediments to America's projection of power. His assertion presumed the United States could shape a more secure and peaceful world through the use of American military and economic power, rather than through adherence to international law. From an 
article by Jim Garamone released on May 7, 2002, Secretary of Defense, Donald

Rumsfeld notifies U.N Secretary General Kofi Annan, of the United States' plans to withdraw from the International Criminal Court Treaty:

The United States has a number of serious objections to the treaty, Rumsfeld said. There is a lack of adequate checks and balances on the powers of ICC prosecutors and judges.

As written, U.S. service members and officials could be charged with war crimes as a political move by other nations. Putting U.S. service members at risk of politicized prosecution, Rumsfeld said, would discourage U.S. military engagement in the world and be a "recipe for isolationism."

"We have an obligation to protect our men and women in uniform from this court and to preserve America's ability to remain engaged in the world," he said. "And we intend to do so."

The treaty would have caused problems at any time, Rumsfeld said, but they are "particularly troubling in the midst of a difficult, dangerous war on terrorism. There is a risk that the ICC could attempt to assert jurisdiction over U.S. service members, as well as civilians, involved in counterterrorist and other military operations -- something we cannot allow." (Department of Defense News, "U.S. Withdraws from International Criminal Court Treaty”, Garamone, J. May 7, 2002)

Rumsfeld's overt indifference toward international protocol is an example of what quickly became the 'new normal' for the United States when addressing a multitude of foreign policy and global issues. Cheney, Gonzalez, and Rumsfeld fit the nationalist paradigm distinctly, and nothing would alter their course of action. This was the perspective of many top officials in the Bush Administration, hyperbolically illustrated by John Bolton, whose tenure as Ambassador to the United Nations set new precedents in American recalcitrance regarding established international standards. As ambassador, he 
unilaterally stalled, ignored, or overturned the following international treaties, agreements, and proposals within the first sixteen months of his term:

- the Kyoto Protocol;

- the International Ban on Torture (IBT);

- the 1972 Anti- Ballistic Missile Treaty (ABM);

- the Comprehensive Test Ban Treaty (CTBT)

- the Small Arms/Light Weapons Treaty.

Bolton attempted, albeit unsuccessfully, to overturn the 1972 Biological Weapons Convention, which he termed "Nixon's unilateral decision to renounce biological warfare, one of those inconvenient facts about unilateralism that the High Minded like to forget" (Surrender is Not an Option: Defending America at the United Nations and Abroad, 2007, p. 92). In his official capacity as ambassador, Bolton joined Rumsfeld in casually dismissing the principles put forth by the International Criminal Court. Bolton's ardent unilateral perspective regarding international protocol is exemplified when he writes, “...I saw treaties as essentially only political documents, and the whole debate over what was 'legally binding' in 'international law,' as just another theological exercise..." (p. 76). Furthermore, he openly boasted of his success in preventing the implementation of countless international treaties as his greatest accomplishment at the $\mathrm{UN}$ :

With persistence and hard work, President Bush's position prevailed. The ABM Treaty is dead, the CTBT Treaty will never come into force, the small-arms/light 
weapons issue has been put its proper place, and the United States has kept its independence from the ICC. (2007, p. 100)

But most important was the inexorable determination of the Bush Administration to remain exempt from prevailing statutes regarding unilateral military action. Throughout his brief tenure, Bolton repeatedly excoriated the United Nations and warned other nations against using preemptive military action. Regardless, the administration had surmised its right to engage in preemptive war as irrefutable:

The United States will not use force in all cases to preempt emerging threats, nor should nations use preemption as a pretext for aggression [italics mine]. Yet in an age where the enemies of a civilization openly and actively seek the world's most destructive technologies, the United States cannot remain idle while dangers gather. (NSS, 2002, p. 15)

Amidst a growing list of unprecedented unilateral actions by the Bush

Administration, information was disclosed in a 2002 report by the Congressional Research Service, titled The Nuclear Posture Review: Overview and Emerging Issues regarding nuclear capability of the United States. Until this point in history, the hypothetical use of nuclear weapons could only be justified as a last resort, and as a defensive measure. In the scenario posited in the Nuclear Posture Review (2001), the right of preemption put forth in the Bush Doctrine was extended to include the offensive use of nuclear weapons:

The Bush Administration plans to retain a greater number of nuclear weapons for a longer period of time than had been planned under START II. And the Administration has not ruled out the development of new nuclear Weapons. Furthermore, it has grouped nuclear weapons and conventional weapons together as "offensive strike weapons." (CRS report to Congress on the Nuclear Posture Review, 2002, p. 6) 
These unprecedented actions by the Bush Administration illustrated a brazen disregard and open contempt for dialogue, diplomacy, multilateralism, and international law. The derision aimed at 'inconvenient obstacles'—including established nuclear treaties and the International Criminal Court—-began in the White House, made its way through the Department of State, the Department of Defense, the National Security Agency, the Central Intelligence Agency, and the mainstream media inside the United States, landing unceremoniously on the doorstep of the United Nations.

American hubris did not sit well with the international community; however, the momentum of the administration's policies was increasing exponentially, but at this juncture, world opinion was merely an inconvenience:

Finally, given the nationalism that animates U.S. policies, American behavior abroad inevitably appears hypocritical to others. This hypocrisy is especially glaring when the United States undermines global institutions in the name of defending American sovereignty (such as in the cases of the Kyoto Protocol, the International Criminal Court, and the Comprehensive Test Ban Treaty). The rejection of such multilateral agreements may score points at home, but nonAmericans have difficulty reconciling the universalistic rhetoric and ideals Americans espouse with the parochial national interests the U.S. government appears determined to pursue abroad. Over time, such behavior... erodes the United States' international credibility and legitimacy. (Pei, 2008, p. 36)

The Bush Doctrine was comprised of many elements, the most notable being the explicit claim of absolute American sovereignty, a central theme in nationalist narratives. This claim encompassed countless elements, many of which remain unprecedented in American foreign policy. From the specious justification of torture, to the envisaged offensive use of nuclear weapons, the Bush Doctrine set new standards in unilateral 
posturing and action. The 2001 Nuclear Posture Review, penned by Rumsfeld and his advisors, was a precursor to the 2001 Quadrennial Defense Review (QDR), whose architects hailed from the corridors of the PNAC. The NPR and the QDR were both drawn from extensively in the formulation of the 2002 National Security Strategy (NSS). Although a key group of neoconservative American intellectuals insisted the Bush Doctrine was not a revolutionary edict, it would be injudicious to abrogate evidence that clearly disputes that premise. "America did not change on September 11. It only became more itself" (Kagan, 2003, p. 85). According to Kaplan and Kristol, the United States did not invade Iraq preemptively, it was merely following the laws and sanctions issued by the UN-all of which were repeatedly ignored by Saddam Hussein. From Kaplan and Kristol's perspective, international law was not violated, it was simply enforced (2003). Although these authors are in concurrence, it is problematic to contend that the Bush Administration's willingness to engage in preemptive war-deemed illegal by Kofi Annan (see Literature Review) — and to openly ignore international law by torturing detainees (while refusing to grant them prisoner-of-war status) was anything other than precedent-setting. It seemed that the administration dismissed any moral, ethical, or historical adherence to accepted international protocol. Such an uncompromising worldview reveals, at its core, a philosophy grounded firmly in nationalist affinities. Long after the invasion of Iraq, negotiation, diplomacy, and rapprochement, all remained anathemas to neoconservatives and their particular brand of American nationalism. According to Khan (2004), the Bush Doctrine greatly weakened the position 
of the United States throughout the world, especially in Muslim countries, potentially resulting in an increased militaristic global paradigm, rather than a reduction of those tendencies. Danner (2014) expresses a similar theory:

The United States' actions in Iraq - rather than increasing America's strength and influence in the world - actually exposed a much greater weakness: The invasion had produced not the rapid and overwhelming victory Cheney had anticipated but a quagmire in which the American military had occupied and repressed a Muslim country and, four years later, had been brought to the verge of defeat. (p. 49)

Opponents and critics of the Bush Doctrine maintain that these policies are ultimately damaging and increase the dangers of terrorism, isolationism, and protracted international conflict. (Anastasiou, 2009; Bacevich, 2008; Boggs, 2004; Cauthen, 2004; Danner, 2014; Gupta, 2008; Hopkins, 2007; and Khan, 2004; McCartney, 2004; Parenti, 2003; Pei, 2003).

Proponents of the Bush Doctrine, however, have the opposing vision for the future of the United States, one in which it becomes a benevolent global hegemon. In this scenario, the United States will utilize its unrivaled military power to liberate oppressed peoples from despotic regimes around the world, spreading its foundational belief in democracy, freedom, and a free market economy in the process (Blankley, 2009; Bolton, 2007; Bush, 2003; Kagan, 2003; Kaplan and Kristol, 2003; Owens, 2008; PNAC, 2000; Podhoretz, 2007; Rumsfeld, 2002). Proponents of the doctrine fail to identify and name its nationalist elements, while maintaining an absolutist view of national security that is a above international law, including: the use of preemptive military force as the primary solution to international disputes; the willingness to sacrifice lives of its citizens; the 
obstinate rejection of previously accepted international protocols; and, an unequivocal dismissal of responsibility for the consequences of its actions.

\section{America's Image Gap}

In reaction to the events of September 11, much of the world reacted with earnest sympathy for the United States, but it quickly dissolved into suspicion and unease. Once the Bush Administration's dramatic new foreign policy doctrine was unveiled and implemented, it left a wake of destruction measured in terms of exiled populations, shredded social fabric, civil strife, sectarian violence, and a marked increase in global terrorism. After the invasions of Afghanistan and Iraq, and particularly the revelation of the United States' use of torture, it is no surprise that mistrust and suspicion of the United States increased worldwide. In fact, world opinion of the U.S. declined sharply throughout the tenure of the Bush Administration.

According to Kofi Annan, "Among the people of the Muslim world, reeling from the impact of these wars, nothing did more damage than the abuses and crimes that took place at detention centers such as Abu Ghraib" (2012, p. 264). These negative opinions were not exclusive to American foreign policy: an underlying and prescient apprehension remained regarding global economic issues, the catalyst being unregulated 'free market' economics, enthusiastically championed by the global financial elite. The following is from a report by Pew Research, (2008):

Since 2002, interviewers have polled over 175,000 people in 54 nations and the Palestinian territories to compare and contrast public opinion around the world on a large variety of subjects. These years coincide almost exactly with the 
presidency of George W. Bush, thus making it possible to assess his impact on matters of concern not just to the United States but to the world. (p. 1)

The findings were stark:

The U.S. image abroad is suffering almost everywhere. Particularly in the most economically developed countries, people blame America for the financial crisis. Opposition to key elements of American foreign policy is widespread in Western Europe, and positive views of the U.S. have declined steeply among many of America's longtime European allies. In Muslim nations, the wars in Afghanistan and particularly Iraq have driven negative ratings nearly off the charts (2008, p. 1).

The Bush Administration however, stayed an unrelenting course, ignoring the consequences of its actions. As Anastasiou (2012) points out, this is a common theme of nationalist thinking, as it presumes that the nation and its actions are beyond reproach or accountability. In this case, the damage to future relations with allies and the opinion of the international community remained inconsequential to the United States; true peace and democracy were anathema to their worldview:

When the protracted use of hard power delegitimizes one's presence in a society and one's standing in the world, it effectively weakens what one can achieve diplomatically and politically, even when one employs non-military means. In effect, it weakens one's capacity to build sustainable relationships among stakeholders, which is the prerequisite of democracy and peace. (Anastasiou, 2012, p. 8)

Similarly, Kofi Annan (2012) writes:

By behaving the way it did, the Unites States invited the perception among many in the world - including many long-time allies - that it was becoming a greater threat to global security than anything Saddam could muster. This was a selfinflicted wound of historic proportions - and one that did immense, and possibly lasting, damage to U.S. standing in the world. (p. 366) 


\section{Authors Addressing American Nationalism}

Tony Blankley's interpretation is similar to that of the proponents of the Bush Doctrine in that he advocates preemptive war, absolute sovereignty, and the expansion of American values throughout the world; however, unlike his contemporaries, he insists that the Bush Doctrine did not go far enough. Anastasiou, McCartney, and Lieven express opposition to the Bush Doctrine, clearly defining American foreign policy from this period as American nationalism. Anastasiou (2009), McCartney (2004), Lieven (2004), and Pei (2003) write of the dangers of preemptive war, proclamations of absolute sovereignty, disregard of international law, each setting the stage for major international conflict, and potentially increasing the threat of terrorism domestically and abroad. McCartney and Lieven both present a future absent of American participation in international dialogue and cooperation.

Anastasiou (2009) introduces numerous approaches to ameliorating conflict historically associated with nationalism, drawing from the fields of conflict analysis and resolution (CAR); conflict resolution (CR), and peace studies (PS):

In attending to the dynamics of protracted conflict, and particularly nationalist conflict, one of the strengths of CAR, CR, and PS lies in their capacity to deconstruct the disputants' vision of the world, policies, and actions, disclosing conflict patterns that bind the rivals to their adversarial relationship, and envision the possibility of peace in light of which to forge proactive perspectives, strategies, and instruments of action. (2009, p. 33)

He suggests that these alternative approaches can be used "as a vital path for belligerents to address, understand, and tackle their conflicts" (p. 34). However, in order to get to the 
point where communication is open, "The challenge...is to affect mutual behavioral change via diplomacy, dialogue acknowledgments, negotiation, and relationship-building instead of resorting to regime change and/or regime defiance via threats, coercion, and firepower and/or various forms of covert violence" (p. 34).

From a peace and conflict studies perspective (Anastasiou, 2009; Barash \& Webel, 2009), nationalism is a historically destructive force. Anastasiou views American nationalism as especially dangerous and potentially calamitous, as the bellicose and narcissistic policies put forth by the Bush Administration rarely differ from their 20th century counterparts, and if unchecked, could lead to the same disastrous conclusions: violence, war, and tragedy. However, Anastasiou sees alternatives to nationalism that, if implemented correctly and effectively, can potentially ameliorate the violent tendencies of nationalism: “dialogue, diplomacy, negotiation and relationship building” (p. 34). Two instances that exemplify this approach are President Obama's recent diplomatic efforts toward negotiation with Iran, and reconciliation with Cuba.

Recognizing and identifying American nationalism as a critical phenomenonwhich academic experts have yet to thoroughly analyze - may provide a coherent and credible interpretive framework for understanding post-9/11 American foreign policy. Although proponents of the Bush Doctrine advocate elements of nationalism, rarely do they reference American exceptionalism as being explicitly nationalist. America's approach to terrorism, national security issues, and international law following September 11,2001 is best understood when viewed through a nationalist lens. 


\section{Conclusion}

From the analysis the following conclusions may be reconciled:

'Neoconservatism,' the strongly ideological movement sprung out of the early 1970s after the demise of Richard Nixon's presidency, laid the groundwork for American nationalism through the theoretical perspective and mentorship of Fritz Kramer. Kramer influenced civilians and military alike with his hard-nosed philosophy — repudiating the value of diplomacy and international law, increasing military spending to astronomical levels, and eliciting an obsessive fear of "provocative weakness" (Colodny \& Schactman, 2010, p. 3). Kraemer's legacy maintained leverage in U.S. foreign policy circles and held sway over many of the architects of the Bush Doctrine, namely those who became members of the Project for a New American Century (PNAC), and thereafter, members of the George W. Bush Administration, including, Dick Cheney, and Donald Rumsfeld.

It is important to readdress the 3 hypotheses posed earlier to examine whether or not they are supported by the subject matter put forth in this study:

In support of the first hypothesis, which theorizes that advocates of the Bush Doctrine are speaking from a nationalist perspective, although they do not make reference to American nationalism (with the exception of two authors-Robert Kagan and Tony Blankley), none of those who support of the Bush Doctrine address nationalism in their literature or policy documents. Kagan uses the term "universal nationalism" on one occasion (2003, p. 76). Blankley (2009), the only self-proclaimed nationalist in the group, insists without equivocation that the Bush Doctrine is still weak, ineffective, and ultimately moribund. 
He believes the primary answer to all foreign policy conflicts is the United States' military, and that the United Nations (and all other international organizations) are inane. Therefore, the second hypothesis, which states that advocates of the Bush Doctrine are speaking from a nationalist perspective but do not name it—is primarily substantiated, with the exception of one strong advocate of American nationalism, and the other, as a passive reference.

Critics of the Bush Doctrine are much less restrained in their labeling of the policy doctrine as "nationalistic." In fact, much of the literature examined in this thesis was chosen specifically because of its direct references to nationalism (See: Alter, Anastasiou, Blankly, Ignatieff, Leiven, McCartney, and Pei). The second hypothesis maintains that those who criticize the Bush Doctrine and make no reference to American nationalism are in actuality, implicating its repercussions on American foreign policy (See: Annan, Bacevich, Boggs, Danner, Guerlin, Gupta, Khan, and Olshansky). And finally, the third hypothesis, which stresses the importance of identifying and understanding American nationalism, in order to assess its implications on future US foreign policy, is clearly exemplified in the following description of the phenomenon. With the introduction of the Bush Doctrine in September 2002, the United States government defined its post 9/11 foreign policy perspective: nationalism became a predominant force in U.S. foreign policy.

The fundamental components of American nationalism, American Exceptionalism, and Universal Nationalism are: 
- The unequivocal contention that the United States has the right to preemptively invade any country in which it perceives a threat to national security.

- The commitment to engage in perpetual war against an almost unlimited number of countries, in order to achieve and maintain goals in the national interest.

- The unyielding entitlement of absolute sovereignty: this encompasses a worldview that insists on complete independence from international law, international protocol, and international organizations. Diplomacy, once a tool of prevention and International cooperation, is now viewed as an obstacle of national independence.

- The belief that American values, democracy, and freedom, are universal; hence, that American hegemony is ultimately beneficial to all.

Hallmarks include massive national defense spending, accompanied by aggressive military posturing and defense policies, as well as enmification of targeted nation-states.

Using the palpable sense of fear experienced by American citizens following the events of September 11 as justification, these policies - whether in the Patriot Act, or the National Security Strategy of 2002 — suspended many of the rights and protections guaranteed by the Constitution. With this in mind, what are the implications for future foreign policy strategies? President Barack Obama's foreign policy has been considerably less belligerent than his predecessor's, but strong elements of nationalism smolder just below the surface - evidenced by reactions of many conservatives in Congress at Obama's diplomatic overtures to Iran regarding uranium enrichment and nuclear proliferation. With numerous experiences in overly ambitious, yet unsuccessful foreign policy exploits over the last decade, it is perplexing to witness the persistent and insidious power of nationalism. If the hypotheses presented herein prove to be accurate and the phenomenon is not scrutinized more thoroughly, nationalism will continue to advance. How might nationalist momentum be curbed? More than ten years after the invasion of 
Iraq, the leaders of that war have yet to issue a single apology or statement resembling an admission of fault or failure. They are relentlessly insistent that their actions were just.

Without the ability to recognize the dangers with nationalist narratives, and their influence on American foreign policy, the actions of the Bush Administration will remain an enigma. Understanding, and transcending American nationalism is essential in developing proactive foreign policy strategies. The question remains: will nationalism continue to influence U.S. foreign policy, or will future administrations discontinue those policies and rejoin the international community in pursuit of dialogue, diplomacy, and negotiation? 


\section{References}

Alter, P. (1995). Nationalism (2nd ed.). Auckland, NZ: Edward Arnold.

Anastasiou, H. (2008). The broken olive branch: Nationalism, ethnic conflict, and the quest for peace in Cyprus (Vol. 1). Syracuse, NY: Syracuse University Press.

Anastasiou, H. (2009). Encountering nationalism: The contribution of peace studies and conflict resolution. Handbook of conflict analysis and resolution. New York, NY: Routledge.

Anastasiou, H. (2011) A Conflict Analysis and Peace Studies Perspective on American Nationalism and US Foreign Policy: The Narrative of American Nationalism versus American Democracy. For presentation at the Annual Conference of the International Studies Association, Montreal, Canada, March 2011.

Annan, K. (2012). Interventions: A life in war and peace. New York, NY: Penguin Books. Bacevich, A.J. (2008) The limits of power: The end of American exceptionalism. New York, NY: Metropolitan Books.

Blankley, T. (2009). American grit: What it will take to survive and win in the $21^{\text {st }}$ century. Washington, D.C.: Regnery Publishing.

Boggs, C. (2004). US grand strategy and its contradictions. New Political Science, 26(3), 271-291. 
Bolton, J. (2007). Surrender is Not an Option: Defending America at the United Nations and Abroad. New York, NY: Simon and Schuster.

Brzezinski \& Scowcroft (2008). America and the world: Conversations on the future of American foreign policy. New York, NY: Basic Books.

Bush, G.W. (2001). George W. Bush: Address to a joint session of Congress on the 9/11 attacks. Transcription by Michael Eidenmuller. Retrieved from $<\underline{\mathrm{http}}$ :/// www.americanrhetoric.com>.

Cauthen, B. (2004). Covenant and continuity: Ethno-symbolism and the myth of divine election. Nations and Nationalism, 10(1/2), 19-33.

Colodny, L. \& Shachtman, T. (2009). The forty years war: The rise and fall of the Neocons, from Nixon to Obama. New York, NY: Harper Collins.

Congressional Research Service. (2002). Report to Congress on the nuclear posture review. Retrieved from $<$ http://www.defense.gov/news/jan2002/ d20020109npr.pdf $>$

Congressional Research Service. (2009). U.N. convention against torture (CAT): Overview and application to interrogation techniques. New York, NY: Michael John Garcia. Retrieved from < $<$ https://www.fas.org/sgp/crs/intel/RL32438.pdf $>$ Danner, M. (2014). Why we live in Rumsfeld's ruins. The New York Review of Books, $\operatorname{LXI}(2)$.

Geneva Conventions Article 129 Relative to the Protection of Civilian Persons in Time of War. (1949). Retrieved from $<\underline{\text { http://www.refworld.org/docid/3ae6b36d2.html }>}$ 
Gonzalez, A. (2002). Memorandum for the President. Decision RE Application of the Geneva Conventions on Prisoners of War to the Conflict with Al Queda and The Taliban. Retrieved from $<\underline{\text { http://www.hereinreality.com/ }}$ alberto gonzales torture memo.html\#.VG0edoes1Ew>

Guerlain, P. (2006). New warriors among American foreign policy theorists. The South Atlantic Quarterly, 105(I), 109-124.

Gupta, S. (2008). The doctrine of pre-emptive strike: Application and implications during the administration of President George W. Bush. International Political Science Review, 29, 181-196.

Hopkins, A.G. (2007). Capitalism, nationalism and the new American empire. The Journal of Imperial and Commonwealth History, 35(1), 95-117.

Ignatieff, M. (1993). Blood and belonging: Journeys into the new nationalism. London: BBC Books.

International Committee of The Red Cross. (2007). Report on the treatment of fourteen "high value detainees" in CIA custody. Retrieved from $<\underline{\mathrm{http}}$ :// assets.nybooks.com/media/doc/2010/04/22/icrc-report.pdf $>$

Kagan, R. (2008). The September 12 paradigm. Foreign Affairs, 87(5), 25-39.

Kagan, R. (2004). Of paradise and power: America and Europe in the new world order. New York: Vintage Books.

Kaplan, L.F \& Kristol, W. (2003). The war over Iraq: Saddam's tyranny and America's mission. San Francisco: Encounter Books. 
Khan, M.A. (2004). The postmodern empire: The United States' new foreign policy and its global challenges. Brown Journal of World Affairs, X(2), 271-283.

Levinger, M. \& Lytle, P. (2001). Myth and mobilization: The triadic structure of nationalist rhetoric. Nations and Nationalism 7 (2), 175-194.

Lieven, A. (2004). Demon in the cellar. Carnegie: Prospect Magazine, 1-6.

McCartney, P. T. (2004). American nationalism and U.S. foreign policy from September 11 to the Iraq war. Political Science Quarterly, 119 (3), 399-423.

McCoy, A. (2006). A Question of Torture: CIA Interrogation, From the Cold War to the War on Terror. Metropolitan Books, New York.

O’Connell, M. (2001). UN Resolution 1441: “Compelling Saddam, Restraining Bush”. Retrieved from $<$ http://jurist.org/forum/forumnew73.php $>$

Olshansky, B. (2007). Democracy detained: Secret unconstitutional practices in the U.S. war on terror. New York, NY: Seven Stories Press.

Owens, M.T. (2008). The Bush Doctrine: The foreign policy of republican empire. Foreign Policy Research Institute, 23-40.

Pew Research. Global Public Opinion in the Bush Years, 2001-2008: America's Image, Muslims and Westerners, Global Economy, Rise of China. (2008). Retrieved from $<$ http://www.pewglobal.org/2008/12/18/global-public-opinion-in-the-bushyears-2001-2008/\#>

Pei, M. (2003). The paradoxes of American nationalism. Foreign Policy Magazine, May 3,2003 . 
Podhoretz, N. (2007). World war IV: The long struggle against Islamofascism.

New York, NY: Doubleday.

Smith, A.D. (1993) Nationalism.

Polity Press. Cambridge, CB2 1UR, UK

The Project for a New American Century. (2000). Rebuilding America's Defenses, Statement of Principles. Retrieved from $<\underline{\mathrm{http}: / /}$ www.informationclearinghouse.info/pdf/RebuildingAmericasDefenses.pdf $>$

The Quadrennial Defense Review of The United States of America, (2001). Retrieved from $<$ http://www.defense.gov/pubs/qdr2001.pdf $>$

Townhall. (2014). Retrieved from $<\underline{\text { http://townhall.com/columnists/tonyblankley/ }>}$

United Nations. (2000). Convention against torture and other cruel, inhuman, or degrading treatment or punishment. New York, NY.

United States Department of Defense. (2002). Secretary Rumsfeld statement on the ICC treaty. Washington, D.C. Retrieved from defense.gov/newsarticle.aspx?id=44089

VandeHei, J. \& Lynch, C. (2005, August 2). "Bush names Bolton U.N. Ambassador in recess appointment." The Washington Post. Retrieved from $<\underline{\mathrm{http}: / /}$ www.washingtonpost.com/wp-dyn/content/article/2005/08/01/ $\underline{\text { AR2005080100436.html > }}$

The White House. (2002). The national security strategy of the United States of America. Retrieved from $<$ http://www.state.gov/documents/organization/63562.pdf $>$ 